\title{
Repurposing existing drugs for COVID-19: an endocrinology perspective
}

Flavio A. Cadegiani(1)

\begin{abstract}
Background: Coronavirus Disease 2019 (COVID-19) is a multi-systemic infection caused by the novel Severe Acute Respiratory Syndrome Coronavirus 2 (SARS-CoV-2), that has become a pandemic. Although its prevailing symptoms include anosmia, ageusia, dry couch, fever, shortness of brief, arthralgia, myalgia, and fatigue, regional and methodological assessments vary, leading to heterogeneous clinical descriptions of COVID-19. Aging, uncontrolled diabetes, hypertension, obesity, and exposure to androgens have been correlated with worse prognosis in COVID19. Abnormalities in the renin-angiotensin-aldosterone system (RAAS), angiotensin-converting enzyme-2 (ACE2) and the androgen-driven transmembrane serine protease 2 (TMPRSS2) have been elicited as key modulators of SARSCoV-2.

Main text: While safe and effective therapies for COVID-19 lack, the current moment of pandemic urges for therapeutic options. Existing drugs should be preferred over novel ones for clinical testing due to four inherent characteristics: 1. Well-established long-term safety profile, known risks and contraindications; 2. More accurate predictions of clinical effects; 3. Familiarity of clinical management; and 4. Affordable costs for public health systems. In the context of the key modulators of SARS-CoV-2 infectivity, endocrine targets have become central as candidates for COVID-19.

The only endocrine or endocrine-related drug class with already existing emerging evidence for COVID-19 is the glucocorticoids, particularly for the use of dexamethasone for severely affected patients. Other drugs that are more likely to present clinical effects despite the lack of specific evidence for COVID-19 include anti-androgens (spironolactone, eplerenone, finasteride and dutasteride), statins, N-acetyl cysteine (NAC), ACE inhibitors (ACEi), angiotensin receptor blockers (ARB), and direct TMPRSS-2 inhibitors (nafamostat and camostat). Several other candidates show less consistent plausibility. In common, except for dexamethasone, all candidates have no evidence for COVID-19, and clinical trials are needed.

Conclusion: While dexamethasone may reduce mortality in severely ill patients with COVID-19, in the absence of evidence of any specific drug for mild-to-moderate COVID-19, researchers should consider testing existing drugs due to their favorable safety, familiarity, and cost profile. However, except for dexamethasone in severe COVID-19, drug treatments for COVID-19 patients must be restricted to clinical research studies until efficacy has been extensively proven, with favorable outcomes in terms of reduction in hospitalization, mechanical ventilation, and death.
\end{abstract}

Keywords: COVID-19, SARS-CoV-2, ACE2, TMPRSS2, Pandemic

Correspondence: flavio.cadegiani@unifesp.br; f.cadegiani@gmail.com

Adrenal and Hypertension Unit, Division of Endocrinology and Metabolism,

Department of Medicine, Escola Paulista de Medicina, Universidade Federal

de São Paulo (EPM/UNIFESP), Rua Pedro de Toledo 781 - 13th floor, São

Paulo, SP 04039-032, Brazil

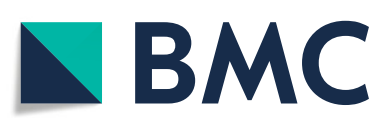

(c) The Author(s). 2020 Open Access This article is licensed under a Creative Commons Attribution 4.0 International License, which permits use, sharing, adaptation, distribution and reproduction in any medium or format, as long as you give appropriate credit to the original author(s) and the source, provide a link to the Creative Commons licence, and indicate if changes were made. The images or other third party material in this article are included in the article's Creative Commons licence, unless indicated otherwise in a credit line to the material. If material is not included in the article's Creative Commons licence and your intended use is not permitted by statutory regulation or exceeds the permitted use, you will need to obtain permission directly from the copyright holder. To view a copy of this licence, visit http://creativecommons.org/licenses/by/4.0/. The Creative Commons Public Domain Dedication waiver (http://creativecommons.org/publicdomain/zero/1.0/) applies to the data made available in this article, unless otherwise stated in a credit line to the data. 


\section{Background}

Coronavirus Disease 2019 (COVID-19) is a multisystemic infection caused by the novel Severe Acute Respiratory Syndrome Coronavirus 2 (SARS-CoV-2), from the coronaviridae family. Some of the specific characteristics found in SARS-CoV-2, including long periods of incubation and shedding, large percentage of asymptomatic and pre-symptomatic infected subjects that may transmit the virus, and the prolonged resistance in surfaces [1-3], are plausible explanations for the inability to contain the SARS-CoV-2 spread, resulting in the current pandemic, although its mechanisms are still not fully elucidated, and may vary according to mutations that SARS-CoV-2 undergoes.

Prevailing symptoms in COVID-19 include anosmia, ageusia, dry couch, fever, shortness of brief, arthralgia, muscle soreness, fatigue, gastrointestinal symptoms, testicular and breast pain. However, slight mutations in the virus and variations in methodological assessments leads to heterogeneous clinical descriptions of COVID-19.

Besides age, data from regions with distinct epidemiological patterns consistently demonstrated that four other major factors are correlated with worse prognosis in SARS-CoV-2: uncontrolled diabetes, hypertension, obesity, and in-tissue exposure to androgens [3-9].

The unique SARS-CoV-2 characteristics and its unprecedented mechanisms of actions challenge the precise description of its mechanisms of actions and pathogenicity [10-15]. The only aspect of SARS-CoV-2 that has demonstrated undisputed characterization is its cell entry, which has shown to be dependent on angiotensinconverting enzyme-2 (ACE2) receptor and transmembrane serine protease 2 (TMPRSS2). While ACE2 is the site of coupling of the spike protein of SARS-CoV-2, TMPRSS2 primes the virus spikes and the ACE2 receptor, allowing its cell entry. The distribution of ACE2 expression in tissues is in fully accordance with the clinical manifestations of COVID-19, that has demonstrated to be multisystemic, although predominantly pulmonary, reinforcing the ACE2-centered hypothesis in COVID-19.

In addition, the vascular system, also largely affected in COVID-19, also induces pulmonary manifestations, since vascularity is critical for respiratory function. Conversely, to date, the only known regulators of TMPRSS2 expression are androgens, which may explain the prevailing presence of males in severe COVID-19, in particular those with androgenetic alopecia (AGA), in which TMPRSS2 expressed seems to be more expressed than in non-AGA males, due to increased hyperandrogenic hormones, specially 5-alpha dihydrotestosterone (5alpha-DHT), enhanced androgen receptor sensibility, or both $[8,9]$.

The understanding of the natural course of SARSCoV-2 is imperative to provide hypotheses for potential therapeutic targets for COVID-19. Currently, COVID-19 can be divided into three stages, although further findings may lead to changes in the understanding of COVID-19 natural history of the disease. The first stage encompasses the period of SARS-CoV-2 viral infection, usually takes between five and ten days, and is dependent on ACE2 attached to surfaces, which seems to regulate the viral cell entry and infectivity, while free circulating ACE2 may preclude from viral infectivity by coupling with SARS-CoV-2 [16-19]. In this stage, since TMPRSS2 facilitates virus cell entry, its expression is also directly correlated with SARS-CoV-2 infectivity.

Unlike the first stage, common to all infected subjects, the second and third stages of COVID-19 are not obligatorily present, and depend on individual characteristics and predisposition. The second stage corresponds to the exacerbated inflammatory reactions to SARS-CoV-2. The second stage typically begins after the downregulation of membrane ACE2 due to its endocytosis that occurs in the first stage. Oppositely to what has been hypothesized for the first stage, increased attached ACE2 during the second stage is likely correlated with favorable outcomes, since ACE2 may limit the cytokine storm that underlies the Acute Respiratory Distress Syndrome (ARDS) in COVID-19.

In addition to the downregulation of attached ACE2 expression, the overexpression of the pro-inflammatory angiotensin II-angiotensin receptor type 1 (AT1) axis and the under-expression of the anti-inflammatory angiotensin 1-7 - G-coupled Mas receptor axis may contribute to the abnormal responses that lead to the cytokine storm, that determines the progression to the third phase, that corresponds to acute lung injury and related dysfunctions.

From the learnings on SARS-CoV-2 mechanisms of infection and disease, the complex relationship between ACE2 and SARS-CoV-2 has been demonstrated to be key to predict COVID-19 severity: while increased circulating ACE2 may provide protection by inhibiting SARSCoV-2 coupling to attached ACE2, a dual correlation between lung membrane-attached ACE2 and COVID-19 has been demonstrated, since during the viral replication the ACE2 expression may enhance viral infectivity, whereas afterwards ACE2 becomes crucial to avoid over-inflammatory and over-immunologic responses, preventing the occurrence of ARDS.

\section{SARS-CoV-2: endocrinological and clinical risk factors related to endocrine-related disorders}

While multiple mechanisms have demonstrated to participate in COVID-19 pathogenesis, the regulation of the Renin-Angiotensin-Aldosterone System (RAAS) has been demonstrated to be critical for the COVID-19 pathogenesis, since angiotensin 1-7 (Ang 1-7), ACE2 and AT1, that participate in the RAAS, are three of the 
four key modulators of SARS-CoV-2 infection patterns. The fourth key regulator of SARS-CoV-2 infectivity is TMPRSS2, which is largely and solely modulated by specific androgens, and depends on androgenic metabolomic profile and androgen receptor (AR) sensibility. In common, all major key mechanisms of SARS-CoV-2 interaction with organism are dependent on overall endocrine functions.

Abnormalities in the RAAS and ACE2 expression as being determinants of COVID-19 severity provide mechanistical substantiation for the overrepresentation of hypertension and obesity as risk factors for COVID19. Conversely, TMPRSS2 overexpression may justify the higher occurrence of COVID-19 complications in males, particularly in those with androgenetic alopecia (AGA), in which TMPRSS2 is likely more activated compared to non-AGA males [8,9]. In addition, up to $40 \%$ of patients with severe SARS-CoV-2 may present underlying silent congestive heart failure (CHF), leading to reduced pulmonary capacity and easier decompensation of cardiovascular and respiratory systems [20]. Together, dysfunctions in the RAAS, ACE2 and TMPRSS2 underlie all major risk factors for severe COVID-19.

In particular for obesity, the most remarkable risk factor in COVID-19, particularly among those below $50 \mathrm{y} / \mathrm{o}$, multiple mechanisms have been proposed to justify the severity of COVID-19, including multiple sites of disruption in the RAAS system, ACE2 expression and activity, associated to an imbalance towards the hypertensive and pro-inflammatory angiotensin II- AT1 axis observed in obese subjects.

Since the RAAS, ACE2 and TMPRSS2 expression encompass virtually all tissues, and their biological actions are not restricted to endocrine regulation, one expects that manifestations related to their dysfunctional expression and activity would not be restricted to endocrine functions. Indeed, the pro-thrombotic state notably present during COVID-19, as well as hematological, kidney, hepatic, cardiovascular, neurological and gastrointestinal manifestations extensively reported in COVID19 [21-47], are largely mediated by abnormalities in the RAAS, ACE2, and TMPRSS2.

In summary, the demonstration that overexpression of attached ACE2 compared to circulating, aberrancies in ACE2 expression and activity, predominant pro-inflammatory angiotensin II-AT1 over angiotensin 1-7-Mas receptor axis, and increased TMPRSS2 expression as keys to determine COVID-19 severity [48-53] allows the hypothesis that regulation of endocrine system may be central for improvement of COVID-19 related outcomes in clinical practice.

\section{Main text}

\section{Strategies against SARS-CoV-2}

The identification of effective treatments to reduce COVID-19 clinical outcomes, mortality and post-
COVID manifestations is highly desired while definitive solutions like effective and safe vaccines are not universally available. Targets that address SARS-CoV-2 mechanisms of infection and risk factors allow proposals of more precise therapies to be potentially effective against COVID-19.

In the current lack of evidence on effective therapies, a major challenge is to identify or discover drugs that delivers high effectiveness, strong safety profile, and affordability for public health systems. In this regard, more than 400 novel drugs including more than 30 biological agents are undergoing clinical trials, among which some may show effectiveness, but will still lack long-term safety profile and is unlikely to be affordable for massive use.

Repurposing existing drugs for COVID-19 should be preferred over the development of new molecules due to four major reasons inherent to long used molecules [5357]: 1 . Well-established short- and long-term safety profile, risks, and contraindications, allowing directed monitoring and lower costs of follow-up and avoiding their use in formally contraindicated populations; whereas newly released drugs require longer studies, thorough monitorization and strict follow-up of special populations, due to the undetermined effects in large populations, since safety profile, detailed risk assessment and detection of uncommon adverse effects and complications can only be obtained in long-term large-scale studies; 2. Mechanisms of action tend to be better elucidated, allowing more precise predictions of clinical effects in COVID-19; 3. Clinicians are more likely familiarized with the clinical management of already existing drugs, including posology, effects, and complications, which is of great importance since the number of infected subjects does not allow COVID-19 to be managed within specialized centers; and 4. For COVID-19, patented drugs will unlikely have sufficient costeffectiveness to justify their use in large scale, once the majority of infected subjects will cure without major clinical complications, irrespective of any treatment. Thus, the number necessary to treat (NNT) will be unconditionally high, which does not support expensive therapeutic options.

In this context, the clinical use prior to specific evidence of efficacy against COVID-19 has been accepted in the current lack of therapeutic options, particularly when risks of complications are high [55-57]. However, the off-label use, termed as compassionate, should be restricted to those steadily safe drugs, as learned from the harms caused by the unrestricted spread use of hydroxychloroquine [58] - which does not hamper from its potential effectiveness, particularly in the first stage of the disease, to be further elucidated.

Considering the current evidence, the employment of currently existing long used drugs should target SARS- 
CoV-2 infectivity, inflammatory response, or both, by addressing at least one of the following: ACE2 timing of expression in the lungs and balance between circulating and membrane-attached ACE2, enhancement of the angiotensin 1-7 axis, inhibition of TMPRSS2 actions, specific antiinflammatory or immune-modulator effects, direct or indirect anti-viral activity, or blockage of harmful effects of dysfunctional RAAS overtly found in obesity.

In this context, endocrine targets have become central, as many of the drugs for the prevailing endocrine or endocrine-related dysfunctions, including anti-diabetics, anti-hypertensives, hormones and have demonstrated effects on one or more sites of actions in COVID-19, once SARS-CoV-2 infectivity and response are highly modulated by different endocrine pathways with strong interactions.

The characteristics to be present within proposed drugs should include well-established risks and contraindications, cardiovascular safety or protection, hematological and vascular safety or protection, with neutral or preventive effects of thromboembolic events, favorable effects on the RAAS and ACE2, neutral or downregulation of the androgen-mediated TMPRSS2, and inhibition or nonexacerbation of acute lung injuries. Drugs that address subclinical CHF and other cardiac dysfunctions may provide independent additional protection, since $\mathrm{CHF}$ and elevated cardiac markers are highly prevalent among hospitalized COVID-19 patients [59-61].

A systematic search of the following terms have been searched in PubMed database: "(name of the drug)" or "(name of the drug class)" or "(hormone)" + "COVID" or "SARS-CoV-2" or "lung injury" or "ARDS" or "viral" or "renin-angiotensin system" or "renin-angiotensin-aldosterone system" or "TMPRSS2" or "ACE2" or" RAAS". In clinicaltrials.gov, search was performed using the expressions "COVID" + "(name of the drug)" or "(name of the drug class)" or "(hormone)".

Candidates for COVID-19 have been ordered according to their likelihood to provide protection for COVID19: 1. Of major relevance: more likely to provide clinical benefits, with preliminary or consistent clinical data on COVID-19; 2. Of moderate relevance: strong plausibility but weak evidence on COVID-19; 3. Of minor relevance: moderate plausibility but solely theoretical; 4 . Discourage use in COVID-19: those that harmful effects may overtake benefits on COVID-19; and 5. A summary of drugs unrelated to the endocrine system with potential benefits for COVID-19.

Data on each drug class as candidate for COVID-19 has been presented following a specific logical sequence: 1. Mechanisms of action that could theoretically provide benefits for COVID-19; 2 . How the drug could be used to treat COVID-19, including the target stages of the disease; and 3. Current specific data on COVID-19, if any.

\section{Candidate drugs against COVID-19}

Several different drugs have elicited hypothetical benefits against COVID-19, including hormones, anti-diabetics and anti-androgens, although the vast majority remains only theoretical, and many of these drugs could provide protection for their regular users, but not necessarily show clinical benefits in COVID-19 if specifically used for this purpose.

\section{Of major relevance}

The only endocrine-related drug class that currently has evidence for COVID-19 are the glucocorticoids. Their use for severe illnesses has dubious and contradictory data $[62,63]$, that seems to depend on the etiology and patterns of lung injury, level of severity, and level of contribution of an overreactive inflammatory response for the severe state, since the two major actions expected from glucocorticoids are their strong anti-inflammatory properties and as enhancers of the physiological response to stress. However, specifically for severe COVID-19, emerged data has been favorable for the use of glucocorticoids, since it has been demonstrated to reduce mortality among hospitalized patients, particularly those in mechanic ventilation [64], which corresponds to the third stage of COVID-19, and 10 currently ongoing clinical trials are testing glucocorticoids in this stage [65]. Conversely, for mild to moderate COVID-19, although the use of corticoids was initially discouraged due to potential delay of viral clearance and increase of viral infectivity [66-68], improvements have been reported when used during the second stage of COVID19, before the development of ARDS [69-74], likely due to glucocorticoid ability to prevent cytokine storm. Since the majority of glucocorticoids has concurrent mineralocorticoid effects, i.e, aldosterone-like actions [75-79], glucocorticoid may enhance the RAAS and mimic detrimental effects of hypertension and obesity in this system, potentially increasing the risks of complications related to COVID-19.

Considering the differences in the characteristics of each corticoid, the specificity of glucocorticoid over mineralocorticoid action when selecting the corticoid to be used should not be despised. In particular, dexamethasone exerts powerful and highly selective glucocorticoid effects, and together with betamethasone, they are the only exogenous corticoids with no mineralocorticoid actions [75-79]. Strong glucocorticoid with absence of mineralocorticoid actions which should be the preferred corticoid regimen for COVID-19, since mineralocorticoid activity may indirectly stimulate viral spread through imbalance between circulating and membrane-attached ACE-2, and deteriorate cardiac and pulmonary functions, central in COVID-19. This may explain the superior efficacy of dexamethasone in severely ill patients 
with COVID-19 [64], although direct comparisons with other glucocorticoids have not been performed.

In summary, glucocorticoids have potential benefits when used in the second stage and demonstrated benefits in the third stage of COVID-19.

\section{Of moderate relevance}

Some drug classes have moderate relevance as candidates for COVID-19 due to their strong plausibility yet weak or null evidence for COVID-19.

Males have been shown to be overrepresented among those severely affected by COVID-19, which remained significant after adjustments for age, body mass index (BMI), and presence of comorbidities [80, 81]. This consistent observation finds plausibility in the active participation of the androgen-driven TMPRSS2 to facilitate SARS-CoV-2 cell entry. However, this correlation is more complex, as young males had better outcomes compared to BMI- and disease-matched older ones, despite having higher testosterone levels, Possibly, intracellular conversion from $\mathrm{T}$ into more androgenic hormones, particularly 5alpha-dihydrotestosterone (5alpha-DHT), may better drive SARS-CoV-2 infectivity, which is supported by the observation that bald men, who typically have higher intracellular DHT levels, are at higher risk of developing severe COVID-19 than their non-bald counterparts [82, 83].

Anti-androgenic approaches intuitively seem to be protective from COVID-19 in males. Indeed, prostate cancer patients receiving androgen-deprivation therapies (ADT) appear to be partially protected from SARS-CoV2 infections [84, 85]. Besides mitigating TMPRSS2 expression [86], androgen-deprivation or antagonizing therapies may suppress the RAAS overexpression induced by androgens, which can be observed in postpubertal males and hyperandrogenic states in females [87-89].

Anti-androgenic therapies encompass those that inhibit the hypothalamic-pituitary-gonadal axis, including modulators of the gonadotrophic inhibitory hormone $(\mathrm{GnIH})$ and Kisspeptin-Kiss1receptor axis and gonadotrophic releasing hormone $(\mathrm{GnRH})$ agonists (leuprolide, goserelin, triptorelin) and antagonists (degarelix), androgen receptor (AR) inhibirors (ARi - cyproterone, spironolactone, eplerenone, flutamide) and 5alpha-reductase inhibitors (finasteride, dutasteride). Among these, AR and 5alpha-reductase inhibitors deserve attention, since they provide prompter anti-androgenic actions and some present additional anti-COVID-19 properties.

The major representatives of $\mathrm{ARi}$ are spironolactone and eplerenone, that also act mineralocorticoid receptor (MR) antagonists, inhibiting aldosterone actions, which represents the bioactive RAAS end-product [90-92]. From these, spironolactone is the most widely commercially available, has an extensive safety profile, is an effective anti-hypertensive, and has demonstrated ability to protect and prevent damage in the heart and kidneys [93-97].

In addition to the protection reported to be provided by spironolactone, specific actions against SARS-CoV-2 actions have been proposed, including increased availability of free circulating ACE2 in response to a hyperreninemic state induced by MR antagonism [98-104], reduction of TMPRSS2 expression due to antagonism of AR [105-107], reversal of RAAS abnormalities induced by obesity $[108,109]$, and possible direct antiinflammatory and anti-viral actions that hamper lung injuries [110-121]. There are currently three ongoing clinical trials with spironolactone [122-124].

Dutasteride and finasteride are the two major 5alphareductase inhibitors used in clinical practice and studied for safety and effective profile in the long run [125-127]. The rationale for their use is based on the blockage of conversion of testosterone into 5alplha-DHT and mitigation of TMPRSS2 expression [128-130], eventually hampering the overrepresentation of males, particularly bald ones, in severe COVID-19. Their benefits may be exhibited if used as a preventive strategy or during the first stage of COVID-19, and has demonstrated correlations with lower severity, although causality could not be established [131, 132]. There is one clinical trial currently testing dutasteride in COVID-19 [133].

Statins (simvastatin, atorvastatin, rosuvastatin, pitavastatin) are inhibitors of the 3-hydroxy-3-methylglutarul-coenzyme A (HMG-CoA) reductase that act primarily as antilipemic agents, with extensive efficacy against cardiovascular events, and pleiotropic anti-inflammatory, antithrombotic, anti-oxidative, immunomodulatory, antiarrhythmic, and direct anti-atherogenic effects [134-136]. From these pleiotropic actions, statins have been purposed to reduce the occurrence and severity of ARDS states and the effects of endotoxin in lung injury [137-141], acting against COVID-19, particularly in the second and third stages [104, 142-145], in addition to the effects on the RAAS, including the decrease of angiotensin II synthesis and action, and reduction of the RAAS-induced oxidative state [146-148]. There are currently five clinical trials [149-153] and one observational study [154] with statins for COVID-19.

Vitamin D is an actual hormone with calcium metabolism, immunologic and metabolic actions. Preliminary observations have correlated vitamin D levels and outcomes in COVID-19, allowing hypotheses on vitamin D as being protective from COVID-19 due to its potential benefits antiviral activity [155-167], attenuation of lung injuries [168-173], and possible slight suppressive although inconsistent effects on RAAS [174-177], and neutral effects on TMPRSS2 [178, 179], being a potential candidate to protect from SARS-CoV-2 infectivity, i.e., 
during its early stage, although only observational studies have been published to date. Despite preliminary reports on hypothetical vitamin D actions on decreasing lung injury severity, this is still only theoretical, and should not be considered as a strong candidate for second and third stages of COVID-19. Currently, 31 studies are evaluating vitamin D supplementation and status in COVID-19, alone or in combination with other therapies [65].

Although used as a nutritional supplement, N-acetyl cysteine (NAC), a precursor of L-cysteine, enhances glutathione elevation biosynthesis and acts as a direct scavenger of free radicals, particularly reactive oxygen species (ROS) [180, 181]. NAS has demonstrated robust antioxidant effects both in vitro and in vivo, and has been successfully employed in a variety of diseases, with emerging evidence in polycystic ovary syndrome (PCOS), fertility abnormalities, chronic inflammation, particularly colitis, acetaminophen intoxication, asthma and neurodegenerative disorders [182]. NAC exerts multiple effects on the modulation of the inflammatory and immunologic responses, including inhibition of the inflammasome pathways [interleukin-1 $\beta$ (IL1 $\beta$ ), IL18, and tumor necrosis factor-a (TNFa)], increase of T cells activity, and improvement of redox status, particularly under intense oxidative stress [183-187], has shown ability to diminish acute lung injuries [188], and may impair ACE2 actions when coupled with SARS-CoV-2 $[189,190]$. Collectively, these mechanisms convey the hypothesis of NAC as a strong candidate against COVID-19 [191, 192], in particular for the second stage, aiming to prevent progression to ARDS, and is undergoing six specific clinical trials [193-198], among which five aim to prevent the occurrence of third stage in COVID-19.

Aspirin is a potent suppressor of prostaglandins and thromboxane A2 (TXA2) generation due to its irreversible inactivation of the cyclooxygenase (COX) enzyme, yielding anti-inflammatory and anti-thrombotic effects, respectively [199]. In addition of its regular use to prevent cardiovascular disease in those at high risk, aspirin may prevent gastrointestinal tract cancers [200-202] and participate in a wide range of different disorders [203], although its effects are highly dependent on the timing and dose administered [204]. While low doses aspirin may play indirect beneficial effects in the RAAS, including suppression of angiotensin II actions, high doses (> $200 \mathrm{mg}$ /day) may hamper cardioprotective and lungprotective effects of the majority of drugs that address RAAS [205-207]. In the lungs, AAS may confer protective effects on the severity of lung injury induced by any endotoxin, and also lower the risk of ARDS, in particular in those previously using aspirin [207-209]. Because of these mechanisms, aspirin has been proposed to protect from COVID-19 during its second and third stages, in special under severe manifestations, and is being tested in ten clinical trials in COVID-19, all aiming to prevent or treat severely ill patients [65]. Other antithrombotic agents, in special the direct inhibitors of factor Xa, apixaban and rivaroxaban, have also demonstrated ability to attenuate lung injury [210, 211], could be potential candidates for the second and third stages of COVID-19, and rivaroxaban is being currently tested for COVID-19 in four clinical trials [212-215].

Although the anti-hypertensive classes of ACE inhibitors (ACEi) and angiotensin receptor blockers (ARB) have been initially correlated with worse outcomes in COVID-19 due to potential SARS-CoV-2 infectivity by the increase of lung membranse-attached ACE2 expression $[11,216,217]$ and preliminary observations that hypertensive patients treated with ACEi or ARB could be at higher risk to develop ARDS and require mechanical ventilation [3, 218-220], not only these correlations have found no corresponding data on larger trials [221, 222], but they have been proposed to be protective, once their direct actions in the RAAS may be clinically helpful during the second stage, in which increased lung membrane ACE2 expression is crucial to prevent cytokine storm, for the balance between angiotensin II and 1-7, and to reduce COVID-19 induced ARDS [223, 224] either if introduced in the second stage of COVID-19, or among those chronic users. The controversy on ACEi, ARB and COVID-19 still remains, including five clinical trials still evaluating whether the use of ACEi and ARB is harmful [124, 225-228], whereas more than 20 clinical trials are testing these classes to reduce COVID-19 severity [65].

In addition to the anti-androgen actions of androgen inhibitors and AR antagonists aiming to reduce TMPR SS2 expression, direct TMPRSS2 blockers through serine protease inhibition have been proposed as potential drugs against COVID-19, including nafamostat, camostat, bromhexine, plasma alpha-1-antitrypsin, leupeptin [229-231]. Among these, nafamostat, a short-action anti-thrombotic with antiviral activity, and camostat have been proposed as treatment options for COVID-19, despite their high costs [230, 231]. There are currently three and eight clinical trials testing nafamostat [232234] and camostat [235-242], respectively.

\section{Of minor relevance}

Drug classes and hormones with merely theoretical plausibility have been listed as of minor relevance for COVID-19.

While males, in particular those affected by androgenetic alopecia (AGA), have been correlated with worse prognosis in COVID-19, this could be explained by AR sensibility and DHT concentrations, rather than testosterone per se, since young males, with the highest 
testosterone levels, are not at higher risk when compared to age-matched young females. Indeed, on the opposite direction, one single study suggested that with lower testosterone concentrations could predict worse outcomes in COVID-19 [243], although low testosterone is more likely a consequence than a cause of COVID-19 severity, since its acute reduction due to suppression of the hypothalamic-pituitary-gonadal (HPG) axis may be directly correlated with level of severity, the hypothalamic hypogonadism that typically occurs in metabolic and inflammatory diseases, including cardiovascular and obesity, corresponds with those at higher risk for severe COVID19 manifestations, which means that hypogonadotrophic hypogonadism and severe COVID-19 are both consequences of a same root cause (inflammatory and metabolic diseases), and indicates that testosterone could be potentially used as an indirect marker, but not necessarily as a candidate as a therapeutic agent for COVID-19.

A potential use of testosterone as a muscle anabolic agent for those recovering from severe COVID-19 could be a matter of discussion, since COVID-19 leads to a sort of muscle hypercatabolic state that leads to disproportionate muscle loss and consequent difficulties in performing basic personal activities, such as raising arms to eat, walking, or even inspiring, in a worse extent than the expected for the time spent in unconscious and in mechanic ventilation. However, while proposed and tested for other cachectic states [244-246], there are no reports on testosterone use for muscular recovery after COVID-19 or ongoing clinical trials on COVID-19.

Estrogens have demonstrated beneficial actions against viral infections and respiratory complications, as clinically observed by better outcomes in women during reproductive age [159, 247-259], due to their protective effect on endothelial function, vasodilation in the pulmonary vasculature, stimulation stimulate of the humoral response to viral infections [159, 247-253], and modulation of inflammatory responses [248, 249], leading to improved outcomes in acute lung injuries of any etiology [254-259]. Estrogens favorably modulates the RAAS in females [260-262], whereas the androgenmediated TMPRSS2 expression has dual correlation with estrogens [248, 263, 264].

However, while COVID-19 has been extensively correlated with thrombotic events of different natures through a range of underlying mechanisms [265-267], and has become a major player in the COVID-19 pathogenesis [267], estrogens have been historically correlated with increased thromboembolic events, which could be a limiting argument for its use in COVID-19. Nonetheless, while endogenous estradiol is only correlated with this nature of events when associated with increased free testosterone and decreased se hormone binding globulin (SHBG) [268], the correlation of exogenous estrogens and thromboembolism is largely justified by the route of administration, orally administered estrogens lead to increased hepatic production of pro-coagulants induced by its first liver first-passage effect, that does not occur in non-oral regimens. Indeed, large observational studies and a meta-analysis have shown no increased risk of thromboembolism among women taking non-oral estrogen replacement therapies [269-271].

Collectively, the prevailing possible protective effect of estradiol against COVID-19 indicates this as a potential therapeutic target for the first and second stages of COVID-19 to prevent more severe complications, although oral regimens must be avoided to prevent synergistic effects with the pro-thrombotic stage inherent to COVID-19.

Type 2 diabetes mellitus (T2DM) has been recognized as a major independent risk factor for severe COVID-19, while the level of glucose control on T2DM may be one of the drivers of severity of COVID-19, particularly before hospitalization, through glucose and non-glucose mediated [272-274]. Overall, in addition to the glucose lowering effects, anti-diabetic drugs may exhibit additional pleiotropic effects specific to each class, that offer unspecific and viral-specific protection patterns, and have been hypothesized as potential agents against COVID-19.

Metformin, the first-line therapy for T2DM with undisputed efficacy and safety and additional antineoplastic, antiaging, anti-inflammatory, immunomodulatory, cardio-, neuro-, hepato-, and nephroprotective actions $[275,276]$, has been proposed as a multi-action protection drug candidate for COVID-19 [277-283], particularly due to its strong systemic reparatory and modulatory mechanisms. While its effects on RAAS seem to be neutral, lung injury can be efficiently prevented and relieved by metformin, specially by the promotion of microvascular repairing actions [284-289], and has also exhibited antiviral activity, enhanced lymphocyte B function and enhanced innate immunity [290-294]. Conversely, metformin has formal contraindication for severe conditions due to the risk of lactic acidosis [295]. For these reasons, metformin could be a candidate for the second stage of COVID-19, before the development of severe respiratory manifestations, although no specific clinical trials are being currently conducted.

Sodium-glucose Co-transporter 2 inhibitors (SGLT2i) (dapagliflozin, empagliflozin, canagliflozin, ipragliflozin, ertugliflozin) are a newly developed anti-diabetic drug class that promotes glycosuria through inhibition of renal glucose reabsorption, alleviating hyperglycemic states. Unexpected improvements of cardiovascular events, overall mortality, liver metabolic dysfunctions, kidney function, and pancreas activity observed in larger 
and longer randomized clinical trials (RCTs) and reallife studies were not completely justifiable by its glucose-, body weight-, and blood pressure-lowering effects [296-298]. Although effects on overall viral replication or lung injury are yet to be unraveled, SGLT2i's have shown active suppression of the overall RAAS due to the negative water balance induced by its concurrent natriuresis, and additional selective mitigation of the angiotensin II-AT1R axis [299-302]. Among SGLT2i, dapagliflozin has been proposed as a protective tool against COVID-19, particularly in the first and second stages, and is currently undergoing two specific clinical trials [303-305].

Analogues of the glucagon-like peptide-1 (GLP-1) class B G-protein-coupled receptor (GLP-1Ra) (lixisenatide, liraglutide, exenatide, dulaglutide, semaglutide) have been first developed to act as glucose-lowering agents. GLP-1Ra have further demonstrated to address obesity, neurodegenerative disorders, have elicited a range of pleiotropic actions due to the wide and heterogeneous distribution of GLP-1R, and have shown to reduce major cardiovascular events, which, cannot be fully justified by improvements in glucose and body weight. GLP-1Ra may exert beneficial effects by controlling glucose levels during infection [306], possibly attenuating lung injury under different circumstances - at least in animal models [307-309] - and restoring lung function in ARDS [310]. GLP-1Ra have also favorable effects on the RAAS by inhibiting angiotensin II while maintaining circulating ACE2 levels [311-315]. Hence, GLP-1Ra has theoretical potential to act in the second stage against COVID-19, although there is no currently ongoing clinical trials for COVID-19.

Dipeptidyl peptidase-4 inhibitors (DPP4i) are antidiabetic drugs that act indirectly enhances incretin hormone actions in a diffuse manner, leading to positive actions in the inflammatory, immunologic, and vascular systems, and consequently has been proposed to be potential candidates against COVID-19 [306, 316-318], currently being tested in two clinical trials. Besides the attenuation of angiotensin II activity [318], DPP4i may also prevent acute lung injury in response to different stressors [319-324] and has shown inhibitory effects on other coronaviruses, including the Middle East Respiratory Syndrome Coronavirus (MERS-CoV) [325-327], which could play protective role in the first and second stages of COVID-19 [328]. Currently, there are four clinical trials testing DPP4i for COVID-19, including two with sitagliptin and two with linagliptin [329-331].

Thiazolidinediones, also termed as glitazones, currently represented by pioglitazone, are nuclear receptor peroxisome proliferator-activated receptor gamma (PPAR $\gamma)$ and partial PPAR $\alpha$ agonists with anti-diabetic and other beneficial metabolic properties. Once PPAR- $\alpha$ and $-\gamma$ agonism exerts multiple metabolic, inflammatory and immunologic benefits, pioglitazone has been proposed as a candidate against COVID-19 [282, 332], despite the lack of current clinical trials to date. Pioglitazone may exert beneficial effects in the RAAS, including marked raise of serum ACE2 levels, which couples with SARS-CoV-2 and preclude viral coupling with attached ACE2 and consequent cell entry, and substantial increase of angiotensin- [1-6] and angiotensin-2 receptor (AT2) concentrations [333-336], undermining angiotensin II actions, may abolish acute lung injury by acting in a range of actions, including positively modulation of macrophage activity, reduction of neutrophil recruitment in response to endotoxin, and reduction of inflammation during sepsis [337-341], and also has direct anti-viral effects [342-345]. Due to its multiple pleiotropic effects, glitazones could theoretically be candidates for all stages in COVID-19 [332], and is currently being tested in one clinical trial [346].

Isotretinoin, a 13-cis-retinoic acid, is a drug extensively used to treat moderate-to-severe acne with vitamin-A like actions, while its metabolites act as retinoic acid receptor (RAR) and retinoid X receptor (RXR) agonists, with pro-apoptotic effects, although its exact mechanisms of actions are not fully elucidated [347, 348]. Despite the lack of reports on prevention or attenuation of lung injury, viral replication, specific immunologic or anti-inflammatory actions, and meaningful actions in the RAAS, isotretinoin has been proposed for the second stage of COVID-19, de due to its anti-inflammatory and immunomodulatory effects, and is being tested in five clinical trials for COVID-19 [349-353].

Rimonabant acts in the endocannabinoid (CB) system, a highly preserved mammalian system that exerts ubiquitous and diverse regulatory actions, including those in metabolism, central nervous system (CNS), inflammatory and immunologic pathways, as a selective CB-1 (cannabinoid receptor subtype 1) antagonist. Rimonabant has been first approved for obesity due to its strong anorexigenic effects [354, 355], but an unacceptable suicide rate has been detected during its post-market clinical trial (CRESCENDO), being withdraw from the market [356]. However, learnings from the CB system encouraged further investigations for the development of improved drugs without psychiatric effects, and has demonstrated mitigation of low-grade inflammation typically observed in obesity $[357,358]$, beneficial effects on the RAAS [359, 360], and immunomodulation [361363], which allowed to propose rimonabant as a candidate for first and second stages in COVID-19 [364, 365], although it could only be tested for strict experimental purposes, since it has been banished since 2010 .

Phosphodiesterase 5 (PDE5) inhibitors (PDE5i), including sildenafil, tadalafil, vardenafil and avanafil, are 
drugs that block the cyclic GMP-specific phosphodiesterase type 5 located in smooth muscle cells, that consequently line vessels in a variety of tissues, leading to tissue-specific vasodilatations. Sildenafil, the first PDE5i, has been first approved to treat erectile dysfunction [366], and has been further extended to primary pulmonary hypertension. In the RAAS, sildenafil has shown to enhance circulating ACE2 concentration and to exert dual effects on the angiotensin II-AT1angiotensin 1-7-AT2 balance, with uncertain effects on COVID-19 [367], while sildenafil may provide protective effects for acute lung injuries due to its abilities to inhibit neutrophilic actions within the lungs and release of pro-inflammatory cytokines, reduce oxidative stress, inhibit apoptosis of epithelial cells, prevent lung edema formation, and improve respiratory parameters [368370]. Positive effects of sildenafil treatment have also been observed with its effects on immunomodulation, angiogenesis, and platelet regulation [370]. The potential benefits of sildenafil on respiratory, inflammatory, vascular, and immunologic parameters based its proposal as a potential drug against COVID-19 [371] that would hypothetically protect in second and third stages, and is being tested in one clinical trial [372].

\section{Discourage use in COVID-19}

Some drug classes not only may show few or no benefits for COVID-19, but may also exhibit deleterious effects that may overcome specific benefits, if any.

While estrogens may present protective effects from COVID-19, their actions in alpha and beta ERs are more complex. Specific selective estrogen receptor modulators (SERMs), including tamoxifen and raloxifene, could theoretically be an additional target to be attempted in COVID-19, despite the lack of any specific data. While raloxifene has been researched for systemic actions, showing to be neutral in the RAAS [373, 374] potentially protective against lung injury [375], and neutral in the cardiovascular system [376], tamoxifen may increase risk of thromboembolic events and stroke when administered orally [377], and does not present any non-oral formulation. Despite the increased risk for thrombosis, which is particularly concerning in the pro-thrombotic state of COVID-19, tamoxifen, not raloxifene, is being currently studied in one clinical trial [350].

Aromatase inhibitors, including anastrozole, letrozole, and exemestane, mitigate testosterone conversion into estrogens, as per its inherent mechanisms of action. Aromatase inhibitors have exhibited harmful effects in the RAAS [378] and indirectly increase of 5alpha-reductase activity and DHT levels [379, 380], enhancing TMPRSS2 expression. Since these effects in the RAAS and TMPR SS2 may potentialize SARS-CoV-2 infectivity and increase risk of thromboembolic events, aromatase inhibitors should be discouraged as candidates for COVID-19.

Unlike estrogens, progestogens lack demonstration of any mechanism of protection from COVID-19, has suppressive effects on both innate and cell-mediated immune responses, in particular inducing T-lymphocyte cell death [381], apparently do not have any major effect in the RAAS [382-384], although hormones with progesterone activity compete with aldosterone in the MR. Because of the suppressing effects on T-lymphocyte, progesterone should be discouraged for COVID-19, despite being currently evaluated for COVID-19 in hospitalized men [385].

\section{Drugs unrelated to the endocrine system}

The present review focused on the potential of endocrine drugs and targets as candidates to protect from COVID-19. However, non-endocrine drugs have shown strong effect and evidence as direct or indirect anti-viral activity [386]. Drug classes unrelated to the endocrine system that have been proposed and are being currently tested for COVID-19 include antiviral drugs (lopinavir/ ritonavir, remdesivir, darunavit/umifenovir, favipiravir, nelfinavir and oseltamivir), broad-spectrum antiparasitic drugs (nitazoxanide, ivermectin), antimalarics (mefloquine, chloroquine and hydroxychloroquine), the anti-alcohol addiction drug disulfiram, and antiinflammatory drugs to modulate immunologic response, including interferons, tocilizumab, and other biological molecules and monoclonal antibodies (baricitinib, sunitinib - AAK1/GAK inhibitors, upadacitinib, tofacitinib JAK inhibitors, and belinostat - HDAC inhibitor) [386].

\section{Final discussion}

Figure 1 summarizes the theoretical potential candidates according to the stages of COVID-19 that they may provide benefits, as well as the list of reasons the support the testing of existing drugs for COVID-19.

Collectively, current understanding shows that SARS$\mathrm{CoV}-2$ infection is enhanced by abnormally high and low attached and circulating ACE2 expression respectively, increased pro-inflammatory angiotensin-II-AT1 axis, reduced anti-inflammatory angiotensin- [1-6]-Mas receptor axes, and increased TMPRSS2 activity. These abnormalities are able to justify obesity, hypertension, and AGA males as being major risk factors of COVID19 complications. Multiple endocrine-related drugs, including hormones, anti-diabetics, anti-androgens and other types of molecules exhibit actions in one or more sites that may inhibit SARS-CoV-2 infectivity, replication, or inflammatory or immunologic overreaction and consequent ARDS. 


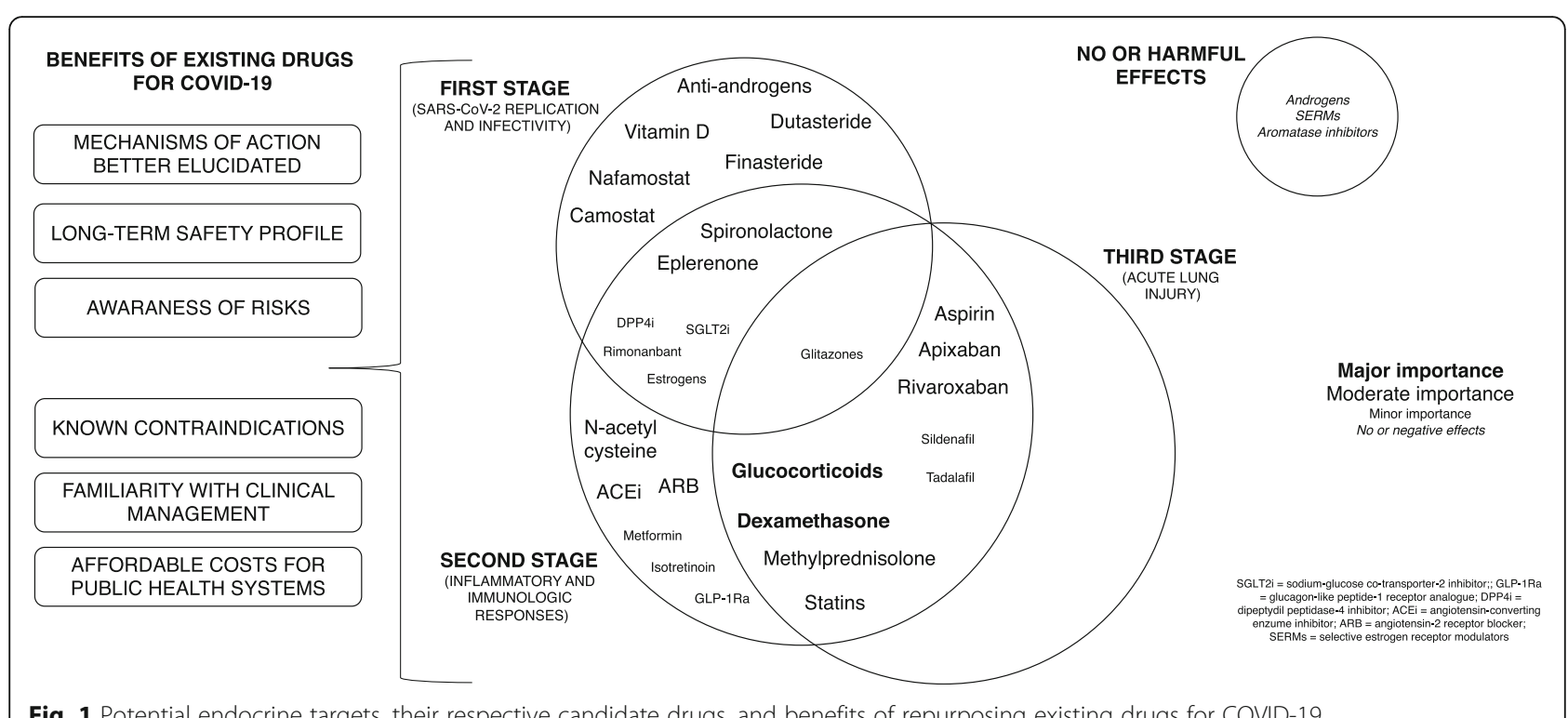

Fig. 1 Potential endocrine targets, their respective candidate drugs, and benefits of repurposing existing drugs for COVID-19

Except for dexamethasone in severe COVID-19, while effective and safe drugs for SARS-CoV-2 lack, researches should be encouraged to consider testing existing drugs with well-established safety profile, known risks and contraindications, notorious clinical management, favorable cost-effectiveness, and promising results in COVID19. Specific combination of some of the candidates for COVID-19 may exhibit synergistic effects for COVID19 , and should also be considered for clinical trials.

Besides tested in clinical trials for COVID-19, drug classes listed as candidates for COVID-19 should also be evaluated in patients using these drugs regular- and chronically for original purposes, before COVID-19 is installed, since acute and chronic use of overall drugs may present distinct effects [387].

Finally, it must be emphasized that regardless of theoretical potential to protect from COVID-19 or preliminary favorable outcomes, drug treatment for COVID-19 patients must be prescribed only after consistent demonstration of efficacy in randomized clinical trials. After proven efficacy, use of drug must be restricted for patients in the specific stage of COVID-19 for which drug has demonstrated efficacy, since drugs can lead to opposite results, as demonstrated with dexamethasone, which while reduced mortality in critically ill patients, subgroup analysis suggested that its use in mild and non-hospitalized patients led to increased mortality [64]. Drugs must prove efficacy in terms of reduction of hospitalization, need of intensive care, mechanical ventilation, and death, and prevention of long-term pulmonary, musculoskeletal, and other physical and mental consequences, in order to be clinically used.

\section{Conclusions}

In the current lack of solid evidence for any specific drug against COVID-19, researchers should consider testing existing drugs with robust long-term safety profile, absence of major risks or life-threatening complications, known contraindications, familiarity in medical community and health care, and plausibility to exhibit protective effects from COVID-19. However, it is mandatory that these drugs are only prescribed in case their efficacy has been proven in clinical trials, and specifically for those patients in the COVID-19 stage for which efficacy has been proven.

\section{Abbreviations}

ACE2: Angiotensin-converting enzyme-2; AT1: Angiotensin receptor-1; AT: Angiotensin receptor-2; CHF: congestive heart failure; COVID-

19: Coronavirus Disease 2019; RAAS: Renin-Angiotensin-Aldosterone System; SARS-CoV-2: Severe Acute Respiratory Syndrome Coronavirus 2; TMPR SS2: Transmembrane serine protease 2

\section{Acknowledgements}

This manuscript should be acknowledged for all researches that have been involved and published the data that supported the present manuscript.

\section{Author's contributions}

FAC developed the central idea, compilated and analyzed the data, and wrote the full version of the present manuscript. The author(s) read and approved the final manuscript.

Funding

No funding was obtained for this study.

Availability of data and materials

There is no additional data than the contained within the present manuscript. 


\section{Ethics approval and consent to participate}

This study did not involve animal or human subjects, and did not require approval from ethical committee.

\section{Consent for publication}

No individual information was used. All authors approved the submitted version of the manuscript.

\section{Competing interests}

The authors declare no financial competing interests.

\section{Received: 16 June 2020 Accepted: 14 September 2020} Published online: 29 September 2020

\section{References}

1. Zhou F, Yu T, Du R, et al. Clinical course and risk factors for mortality of adult inpatients with COVID-19 in Wuhan, China: a retrospective cohort study [published online ahead of print, 2020 Mar 11] [published correction appears in Lancet. 2020 Mar 12:-.]. Lancet. 2020;S0140-6736(20)30566-3.

2. Lauer SA, Grantz KH, Bi Q, et al. The Incubation Period of Coronavirus Disease 2019 (COVID-19) From Publicly Reported Confirmed Cases: Estimation and Application [published online ahead of print, 2020 Mar 10]. Ann Intern Med. 2020;https://doi.org/10.7326/M20-0504.

3. Wu C, Chen X, Cai Y, et al. Risk Factors Associated With Acute Respiratory Distress Syndrome and Death in Patients With Coronavirus Disease 2019 Pneumonia in Wuhan, China [published online ahead of print, 2020 Mar 13]. JAMA Intern Med. 2020;https://doi.org/10.1001/jamainternmed.2020.0994.

4. Guan W, Ni Z, Hu Y, et al. Clinical characteristics of coronavirus disease 2019 in China. N Engl J Med 2020.

5. Hajifathalian K, Kumar S, Newberry C, et al. Obesity is associated with worse outcomes in COVID-19: Analysis of Early Data From New York City [published online ahead of print, 2020 May 29]. Obesity (Silver Spring). 2020; https://doi.org/10.1002/oby.22923

6. Kalligeros M, Shehadeh F, Mylona EK, et al. Association of Obesity with Disease Severity among Patients with COVID-19 [published online ahead of print, 2020 Apr 30]. Obesity (Silver Spring). 2020; https://doi.org/10.1002/oby. 22859.

7. Palaiodimos L, Kokkinidis DG, Li W, et al. Severe obesity, increasing age and male sex are independently associated with worse in-hospital outcomes, and higher in-hospital mortality, in a cohort of patients with COVID-19 in the Bronx, New York [published online ahead of print, 2020 May 16]. Metabolism. 2020;108:154262

8. Goren A, Vano-Galvan S, Wambier CG, et al. A preliminary observation: male pattern hair loss among hospitalized COVID-19 patients in Spain - A potential clue to the role of androgens in COVID-19 severity [published online ahead of print, 2020 Apr 16]. J Cosmet Dermatol. 2020;https://doi. org/10.1111/jocd.13443.

9. Goren A, McCoy J, Wambier CG, et al. What does androgenetic alopecia have to do with COVID-19? An insight into a potential new therapy [published online ahead of print, 2020 Apr 1]. Dermatol Ther. 2020;e13365.

10. Chen Y, Guo Y, Pan Y, Zhao ZJ. Structure analysis of the receptor binding of 2019-nCoV [published online ahead of print, 2020 Feb 17]. Biochem Biophys Res Commun. 2020;S0006-291X(20)30339-9.

11. Hoffmann M, Kleine-Wever H, Kruger N, Muller M, Drotsten C, Pholhlmann S The novel coronavirus 2019 (2019-nCoV) uses the SARS coronavirus receptor ACE2 and the cellular protease TMPRSS2 for entry in target cells. Cell. 2020;181:1-10.

12. Kuba K, Imai Y, Rao S, Gao H, Guo F, Guan B, Huan Y, Yang P, Zhang Y, Deng W, Bao L, Zhang B, Liu G, Wang Z, Chappell MC, Liu Y, Zheng D, Leibbrandt A, Wada T, Slutsky AS, Liu D, Qin C, Jiang C, Penninger JM. A crucial role of angiotensin converting enzyme 2 (ACE2) in SARS coronavirus-induced lung injury. Nature Med. 2005;11:875-9.

13. Xu H, Zhong L, Deng J, Peng J, Dan H, Zeng X, Li T, Chen Q. High expression of ACE2 receptor of 2019-nCoV on the epithelial cells of oral mucosa. Int J Oral Science. 2020;12:8-15.

14. Ortega JT, Serrano ML, Pujol FH, Rangel HR. Role of changes in SARS-CoV-2 spike protein in the interaction with the human ACE2 receptor: An in silico analysis. EXCLI J. 2020;19:410-417. Published 2020 Mar 18.

15. Yan T, Xiao R, Lin G. Angiotensin-converting enzyme 2 in severe acute respiratory syndrome coronavirus and SARS-CoV-2: A double-edged sword? FASEB J. 2020;34(5):6017-26.
16. Zou Z, Yan Y, Shu Y, et al. Angiotensin-converting enzyme 2 protects from lethal avian influenza A H5N1 infections. Nat Commun. 2014:5:3594.

17. Gu H, Xie Z, Li T, et al. Angiotensin-converting enzyme 2 inhibits lung injury induced by respiratory syncytial virus. Sci Rep. 2016;6:19840.

18. Khan A, Benthin C, Zeno B, et al. A pilot clinical trial of recombinant human angiotensin-converting enzyme 2 in acute respiratory distress syndrome. Crit Care. 2017;21:234

19. Batlle D, Wysocki SK. Soluble angiotensin-converting enzyme 2: a potential approach for coronavirus infection therapy? Clinical Science. 2020;134:5435.

20. Arentz M, Yim E, Klaff $L$, et al. Characteristics and outcomes of 21 critically ill patients with COVID-19 in Washington State. JAMA 2020 (Epub ahead of print).

21. Baig AM, Khaleeg A, Ali U, Syeda H. Evidence of the COVID-19 Virus Targeting the CNS: Tissue Distribution, Host-Virus Interaction, and Proposed Neurotropic Mechanisms. ACS Chem Neurosci. 2020;11(7):995-8. https://doi. org/10.1021/acschemneuro.0c00122.

22. Li YC, Bai WZ, Hashikawa T. The neuroinvasive potential of SARS-CoV2 may play a role in the respiratory failure of COVID-19 patients [published online ahead of print, 2020 Feb 27]. J Med Virol. 2020;https://doi.org/10.1002/jmv. 25728.

23. Conde Cardona G, Quintana Pájaro LD, Quintero Marzola ID, Ramos Villegas Y, Moscote Salazar LR. Neurotropism of SARS-CoV 2: Mechanisms and manifestations. J Neurol Sci. 2020;412:116824. doi:https://doi.org/10.1016/j. jns.2020.116824

24. Natoli S, Oliveira V, Calabresi P, Maia LF, Pisani A. Does SARS-Cov-2 invade the brain? Translational lessons from animal models [published online ahead of print, 2020 Apr 25]. Eur J Neurol. 2020;https://doi.org/10.1111/ene. 14277.

25. Helms J, Kremer S, Merdji H, et al. Neurologic Features in Severe SARS-CoV-2 Infection [published online ahead of print, 2020 Apr 15]. N Engl J Med. 2020;NEJMc2008597.

26. Lin L, Jiang $X$, Zhang Z, et al. Gastrointestinal symptoms of 95 cases with SARS-CoV-2 infection [published online ahead of print, 2020 Apr 2]. Gut. 2020;gutjnl-2020-321013

27. Cheung KS, Hung IF, Chan PP, et al. Gastrointestinal Manifestations of SARSCoV-2 Infection and Virus Load in Fecal Samples from the Hong Kong Cohort and Systematic Review and Meta-analysis [published online ahead of print, 2020 Apr 3]. Gastroenterology. 2020;S0016-5085(20)30448-0.

28. Xiao F, Tang M, Zheng X, Liu Y, Li X, Shan H. Evidence for Gastrointestinal Infection of SARS-CoV-2 [published online ahead of print, 2020 Mar 3]. Gastroenterology. 2020;. doi:https://doi.org/10.1053/j.gastro.2020.02.055.

29. Recalcati S. Cutaneous manifestations in COVID-19: a first perspective [published online ahead of print, 2020 Mar 26]. J Eur Acad Dermatol Venereol. 2020;https://doi.org/10.1111/jdv.16387.

30. Mungmungpuntipantip R, Wiwanitkit V. COVID-19 and Cutaneous manifestations [published online ahead of print, 2020 Apr 15]. J Eur Acad Dermatol Venereol. 2020;https://doi.org/10.1111/jdv.16483.

31. Zhu H, Rhee JW, Cheng P, et al. Cardiovascular Complications in Patients with COVID-19: Consequences of Viral Toxicities and Host Immune Response. Curr Cardiol Rep. 2020;22(5):32. Published 2020 Apr 21.

32. Kim IC, Kim JY, Kim HA, Han S. COVID-19-related myocarditis in a 21-yearold female patient [published online ahead of print, 2020 Apr 13]. Eur Heart J. 2020;ehaa288.

33. Kochi AN, Tagliari AP, Forleo GB, Fassini GM, Tondo C. Cardiac and arrhythmic complications in patients with COVID-19 [published online ahead of print, 2020 Apr 9]. J Cardiovasc Electrophysiol. 2020;https://doi.org/ 10.1111/jce.14479.

34. Zeng JH, Liu YX, Yuan J, et al. First case of COVID-19 complicated with fulminant myocarditis: a case report and insights [published online ahead of print, 2020 Apr 10]. Infection. 2020;https://doi.org/10.1007/s15010-02001424-5.

35. Xu L, Liu J, Lu M, Yang D, Zheng X. Liver injury during highly pathogenic human coronavirus infections [published online ahead of print, $2020 \mathrm{Mar}$ 14]. Liver Int. 2020;https://doi.org/10.1111/liv.14435.

36. Lee IC, Huo TI, Huang YH. Gastrointestinal and Liver Manifestations in Patients with COVID-19 [published online ahead of print, 2020 Apr 1]. J Chin Med Assoc. 2020;https://doi.org/10.1097/JCMA.0000000000000319.

37. Musa S. Hepatic and gastrointestinal involvement in coronavirus disease 2019 (COVID-19): What do we know till now?. Arab J Gastroenterol. 2020; 21(1):3-8. doi:https://doi.org/10.1016/j.ajg.2020.03.002. 
38. Fanelli V, Fiorentino M, Cantaluppi V, et al. Acute kidney injury in SARS-CoV2 infected patients. Crit Care. 2020;24(1):155. Published 2020 Apr 16.

39. Chu KH, Tsang WK, Tang CS, et al. Acute renal impairment in coronavirusassociated severe acute respiratory syndrome. Kidney Int. 2005;67(2):698-705.

40. Abobaker A, Raba AA. Does COVID-19 affect male fertility? [published online ahead of print, 2020 Apr 21]. World J Urol. 2020;https://doi.org/10.1007/ s00345-020-03208-w.

41. Cardona Maya WD, Du Plessis SS, Velilla PA. SARS-CoV-2 and the Testis: similarity to other viruses and routes of infection [published online ahead of print, 2020 Apr 17]. Reprod Biomed Online. 2020;doi:https://doi.org/10.1016/ j.rbmo.2020.04.009

42. Klok FA, Kruip MJHA, van der Meer NJM, et al. Incidence of thrombotic complications in critically ill ICU patients with COVID-19 [published online ahead of print, 2020 Apr 10]. Thromb Res. 2020;S0049-3848(20)30120-1.

43. Llitjos JF, Leclerc M, Chochois C, et al. High incidence of venous thromboembolic events in anticoagulated severe COVID-19 patients [published online ahead of print, 2020 Apr 22]. J Thromb Haemost. 2020; https://doi.org/10.1111/jth.14869.

44. Panigada M, Bottino N, Tagliabue $P$, et al. Hypercoagulability of COVID-19 patients in Intensive Care Unit. A Report of Thromboelastography Findings and other Parameters of Hemostasis [published online ahead of print, 2020 Apr 17]. J Thromb Haemost. 2020;https://doi.org/10.1111/jth.14850.

45. Cui S, Chen S, Li X, Liu S, Wang F. Prevalence of venous thromboembolism in patients with severe novel coronavirus pneumonia [published online ahead of print, 2020 Apr 9]. J Thromb Haemost. 2020;https://doi.org/10. 1111/jth. 14830 .

46. Rotzinger DC, Beigelman-Aubry C, von Garnier C, Qanadli SD. Pulmonary embolism in patients with COVID-19: Time to change the paradigm of computed tomography [published online ahead of print, $2020 \mathrm{Apr} 11]$. Thromb Res. 2020;190:58-59. doi:https://doi.org/10.1016/j.thromres.2020.04.011.

47. Giannis D, Ziogas IA, Gianni P. Coagulation disorders in coronavirus infected patients: COVID-19, SARS-CoV-1, MERS-CoV and lessons from the past [published online ahead of print, 2020 Apr 9]. J Clin Virol. 2020;127:104362.

48. Glebov OO. Understanding SARS-CoV-2 endocytosis for COVID-19 drug repurposing [published online ahead of print, 2020 May 19]. FEBS J. 2020; https://doi.org/10.1111/febs.15369.

49. Magrone T, Magrone M, Jirillo E. Focus on Receptors for Coronaviruses with Special Reference to Angiotensin-converting Enzyme 2 as a Potential Drug Target - A Perspective [published online ahead of print, 2020 Apr 27]. Endocr Metab Immune Disord Drug Targets. 2020;https://doi.org/10.2174/ 1871530320666200427112902.

50. Annweiler C, Cao Z, Wu Y, et al. Counter-regulatory 'Renin-Angiotensin' System-based Candidate Drugs to Treat COVID-19 Diseases in SARS-CoV-2infected patients [published online ahead of print, 2020 May 17]. Infect Disord Drug Targets. 2020;https://doi.org/10.2174/ 1871526520666200518073329.

51. Offringa A, Montijn R, Singh S, Paul M, Pinto YM, Pinto-Sietsma SJ. The mechanistic overview of SARS-CoV-2 using angiotensin-converting enzyme 2 to enter the cell for replication: possible treatment options related to the renin-angiotensin system [published online ahead of print, 2020 May 28]. Eur Heart J Cardiovasc Pharmacother. 2020;pvaa053.

52. Liu DD, Hsu YH, Chen HI. Endotoxin-induced acute lung injury is enhanced in rats with spontaneous hypertension. Clin Exp Pharmacol Physiol. 2007; 34(1-2):61-69.

53. Biggest COVID-19 trial tests repurposed drugs first. Nat Biotechnol. 2020;38(5):510.

54. Shaughnessy AF. Old drugs, new tricks. BMJ. 2011;342:d741.

55. O'Connor KA, Roth BL. Finding new tricks for old drugs: an efficient route for public-sector drug discovery. Nat Rev Drug Discov. 2005;4(12):1005-1014.

56. Mercorelli B, Palù G, Loregian A. Drug Repurposing for Viral Infectious Diseases: How Far Are We?. Trends Microbiol. 2018;26(10):865-876.

57. Pandey A, Nikam AN, Shreya AB, et al. Potential therapeutic targets for combating SARS-CoV-2: Drug repurposing, clinical trials and recent advancements [published online ahead of print, 2020 Jun 1]. Life Sci. 2020; 256:117883. doi:https://doi.org/10.1016/j.lfs.2020.117883.

58. Mazzanti A, Briani M, Kukavica D, et al. Association of Hydroxychloroquine with QTc Interval in Patients with COVID-19 [published online ahead of print, 2020 Jun 5]. Circulation. 2020; https://doi.org/10.1161/ CIRCULATIONAHA.120.048476.

59. Inciardi RM, Lupi L, Zaccone G, et al. Cardiac involvement in a patient with coronavirus disease 2019 (COVID-19). JAMA Cardiol2020;March 27:[Epub ahead of print].
60. Arentz M, Yim E, Klaff L, et al. Characteristics and outcomes of 21 critically ill patients with COVID-19 in Washington state. JAMA2020;March 19:[Epub ahead of print].

61. Guo T, Fan Y, Chen M, et al. Cardiovascular implications of fatal outcomes of patients with coronavirus disease 2019 (COVID-19). JAMA Cardiol 2020; March 27:[Epub ahead of print].

62. Mokra D, Mikolka P, Kosutova P, Mokry J. Corticosteroids in Acute Lung Injury: The Dilemma Continues. Int J Mol Sci. 2019;20(19):4765. Published 2019 Sep 25.

63. Tang BM, Craig JC, Eslick GD, Seppelt I, McLean AS. Use of corticosteroids in acute lung injury and acute respiratory distress syndrome: a systematic review and meta-analysis. Crit Care Med. 2009;37(5):1594-1603.

64. Horby P, Lim WS, et al (RECOVERY Collaborative Group). Dexamethasone in Hospitalized Patients with Covid-19 - Preliminary Report [published online ahead of print, 2020 Jul 17]. N Engl J Med. 2020;https://doi.org/10.1056/ NEJMoa2021436.

65. ClinicalTrials.gov (Last accessed July 23rd, 2020).

66. Zhang $W$, Zhao $Y$, Zhang $F$, et al. The use of anti-inflammatory drugs in the treatment of people with severe coronavirus disease 2019 (COVID-19): The Perspectives of clinical immunologists from China. Clin Immunol. 2020;214: 108393.

67. Ma SQ, Zhang J, Wang YS, et al. Glucocorticoid therapy delays the clearance of SARS-CoV-2 RNA in an asymptomatic COVID-19 patient [published online ahead of print, 2020 May 29]. J Med Virol. 2020;https://doi.org/10.1002/jmv. 26086.

68. Russell CD, Millar JE, Baillie JK. Clinical evidence does not support corticosteroid treatment for 2019-nCoV lung injury. Lancet. 2020;395(10223): 473-475.

69. Shang L, Zhao J, Hu Y, Du R, Cao B. On the use of corticosteroids for 2019nCoV pneumonia. Lancet. 2020;395(10225):683-684.

70. Halpin DMG, Singh D, Hadfield RM. Inhaled corticosteroids and COVID-19: a systematic review and clinical perspective. Eur Respir J. 2020;55(5):2001009. Published 2020 May 7.

71. Qin $Y Y$, Zhou $Y H$, Lu YQ, et al. Effectiveness of glucocorticoid therapy in patients with severe coronavirus disease 2019: protocol of a randomized controlled trial. Chin Med J (Engl). 2020;133(9):1080-1086.

72. Wang $Y$, Jiang $W$, He $Q$, et al. A retrospective cohort study of methylprednisolone therapy in severe patients with COVID-19 pneumonia. Signal Transduct Target Ther. 2020;5(1):57. Published 2020 Apr 28. doi: https://doi.org/10.1038/s41392-020-0158-2.

73. Wu C, Chen X, Cai Y, et al. Risk Factors Associated With Acute Respiratory Distress Syndrome and Death in Patients With Coronavirus Disease 2019 Pneumonia in Wuhan, China [published online ahead of print, 2020 Mar 13] JAMA Intern Med. 2020;e200994.

74. Zhou W, Liu Y, Tian D, et al. Potential benefits of precise corticosteroids therapy for severe 2019-nCoV pneumonia. Signal Transduct Target Ther. 2020:5(1):18. Published 2020 Feb 21.

75. Wyrwoll CS, Mark PJ, Waddell BJ. Developmental programming of renal glucocorticoid sensitivity and the renin-angiotensin system. Hypertension. 2007;50(3):579-84.

76. Yongtao Z, Kunzheng W, Jingjing $Z$, et al. Glucocorticoids activate the local renin-angiotensin system in bone: possible mechanism for glucocorticoidinduced osteoporosis. Endocrine. 2014;47(2):598-608.

77. Kino T, Chrousos GP. Glucocorticoid and mineralocorticoid receptors and associated diseases. Essays Biochem. 2004;40:137-55.

78. Fuller PJ, Lim-Tio SS, Brennan FE. Specificity in mineralocorticoid versus glucocorticoid action. Kidney Int. 2000;57(4):1256-64.

79. Rashid S, Lewis GF. The mechanisms of differential glucocorticoid and mineralocorticoid action in the brain and peripheral tissues. Clin Biochem. 2005;38(5):401-9.

80. Pozzilli P, Lenzi A. Commentary: Testosterone, a key hormone in the context of COVID-19 pandemic [published online ahead of print, 2020 Apr 27]. Metabolism. 2020;108:154252.

81. Salonia A, Corona G, Giwercman A, et al. SARS-CoV-2, Testosterone and frailty in males (PROTEGGIMI): A multidimensional research project [published online ahead of print, 2020 May 5]. Andrology. 2020;https://doi. org/10.1111/andr.12811.

82. Wambier CG, Vaño-Galván S, McCoy J, et al. Androgenetic Alopecia Present in the Majority of Hospitalized COVID-19 Patients - the "Gabrin sign" [published online ahead of print, 2020 May 21]. J Am Acad Dermatol. 2020; S0190-9622(20)30948-8. 
83. Wambier CG, Goren A. Severe acute respiratory syndrome coronavirus 2 (SARSCoV-2) infection is likely to be androgen mediated [published online ahead of print, 2020 Apr 10]. J Am Acad Dermatol. 2020;S0190-9622(20)30608-3.

84. McCoy J, Wambier CG, Vano-Galvan S, et al. Racial Variations in COVID-19 Deaths May Be Due to Androgen Receptor Genetic Variants Associated with Prostate Cancer and Androgenetic Alopecia. Are Anti-Androgens a Potential Treatment for COVID-19? [published online ahead of print, 2020 Apr 25]. J Cosmet Dermatol. 2020;https://doi.org/10.1111/jocd.13455.

85. Montopoli M, Zumerle S, Vettor R, et al. Androgen-deprivation therapies for prostate cancer and risk of infection by SARS-CoV-2: a population-based study ( $\mathrm{N}=4532)$ [published online ahead of print, 2020 May 6]. Ann Oncol. 2020;50923-7534(20)39797-0.

86. Iwata-Yoshikawa N, Okamura T, Shimizu Y, Hasegawa H, Takeda M, Nagata N. TMPRSS2 Contributes to Virus Spread and Immunopathology in the Airways of Murine Models after Coronavirus Infection. J Virol. 2019;93(6): e01815-18. Published 2019 Mar 5.

87. Maric-Bilkan C, Manigrasso MB. Sex differences in hypertension: contribution of the renin-angiotensin system. Gend Med. 2012;9(4):287-91.

88. Arefi S, Mottaghi S, Sharifi AM. Studying the correlation of reninangiotensin-system (RAS) components and insulin resistance in polycystic ovary syndrome (PCOs). Gynecol Endocrinol. 2013;29(5):470-3.

89. Mishra JS, More AS, Gopalakrishnan K, Kumar S. Testosterone plays a permissive role in angiotensin II-induced hypertension and cardiac hypertrophy in male rats. Biol Reprod. 2019;100(1):139-48.

90. Georgianos PI, Vaios V, Eleftheriadis T, Zebekakis P, Liakopoulos V. Mineralocorticoid Antagonists in ESRD: An Overview of Clinical Trial Evidence. Curr Vasc Pharmacol. 2017;15(6):599-606.

91. Hermidorff MM, Faria Gde O, Amâncio Gde C, de Assis LV, Isoldi MC. Nongenomic effects of spironolactone and eplerenone in cardiomyocytes of neonatal Wistar rats: do they evoke cardioprotective pathways? Biochem Cell Biol. 2015;93(1):83-93.

92. Cadegiani FA. Can spironolactone be used to prevent COVID-19-induced acute respiratory distress syndrome in patients with hypertension?. Am J Physiol.

93. Nakano S, Kobayashi N, Yoshida K, Ohno T, Matsuoka H. Cardioprotective mechanisms of spironolactone associated with the angiotensin-converting enzyme/epidermal growth factor receptor/extracellular signal-regulated kinases, NAD(P)H oxidase/lectin-like oxidized low-density lipoprotein receptor-1, and Rho-kinase pathways in aldosterone/salt-induced hypertensive rats. Hypertens Res. 2005;28(11):925-36.

94. Dieterich HA, Wendt C, Saborowski F. Cardioprotection by aldosterone receptor antagonism in heart failure. Part I. The role of aldosterone in heart failure. Fiziol Cheloveka. 2005;31(6):97-105

95. Taira M, Toba H, Murakami M, et al. Spironolactone exhibits direct renoprotective effects and inhibits renal renin-angiotensin-aldosterone system in diabetic rats. Eur J Pharmacol. 2008;589(1-3):264-71.

96. Schjoedt KJ. The renin-angiotensin-aldosterone system and its blockade in diabetic nephropathy: main focus on the role of aldosterone. Dan Med Bull. 2011;58(4):B4265

97. Kong EL, Zhang JM, An N, Tao Y, Yu WF, Wu FX. Spironolactone rescues renal dysfunction in obstructive jaundice rats by upregulating ACE2 expression. J Cell Commun Signal. 2019;13(1):17-26.

98. Takeda Y, Zhu A, Yoneda T, Usukura M, Takata H, Yamagishi M. Effects of aldosterone and angiotensin II receptor blockade on cardiac angiotensinogen and angiotensin-converting enzyme 2 expression in Dahl salt-sensitive hypertensive rats. Am J Hypertens. 2007;20(10):1119-24.

99. Zhu A, Yoneda T, Demura M, et al. Effect of mineralocorticoid receptor blockade on the renal renin-angiotensin system in Dahl salt-sensitive hypertensive rats. J Hypertens. 2009;27(4):800-5.

100. Keidar S, Gamliel-Lazarovich A, Kaplan M, et al. Mineralocorticoid receptor blocker increases angiotensin-converting enzyme 2 activity in congestive heart failure patients. Circ Res. 2005;97(9):946-53.

101. Te Riet $L$, van Esch JH, Roks AJ, van den Meiracker $A H$, Danser $A H$. Hypertension: renin-angiotensin-aldosterone system alterations. Circ Res. 2015;116(6):960-75.

102. Hamming I, Cooper ME, Haagmans BL, et al. The emerging role of ACE2 in physiology and disease. J Pathol. 2007;212(1):1-11.

103. Patel $S$, Rauf A, Khan H, Abu-lzneid T. Renin-angiotensin-aldosterone (RAAS): The ubiquitous system for homeostasis and pathologies. Biomed Pharmacother. 2017;94:317-25.

104. South AM, Diz DI, Chappell MC. COVID-19, ACE2, and the cardiovascular consequences. Am J Physiol Heart Circ Physiol. 2020;318(5):H1084-90.
105. Sert M, Tetiker T, Kirim S. Comparison of the efficiency of anti-androgenic regimens consisting of spironolactone, Diane 35 , and cyproterone acetate in hirsutism. Acta Med Okayama. 2003;57(2):73-6.

106. Steelman SL, Brooks JR, Morgan ER, Patanelli DJ. Anti-androgenic activity of spironolactone. Steroids. 1969;14(4):449-50.

107. Broulik PD, Stárka L. Antiandrogenic and antirenotropic effect of spironolactone. Endokrinologie. 1976;68(1):35-9.

108. Vecchiola A, Fuentes CA, Solar I, et al. Eplerenone Implantation Improved Adipose Dysfunction Averting RAAS Activation and Cell Division. Front Endocrinol (Lausanne). 2020;11:223. Published 2020 Apr 21.

109. Feraco A, Armani A, Mammi C, Fabbri A, Rosano GM, Caprio M. Role of mineralocorticoid receptor and renin-angiotensin-aldosterone system in adipocyte dysfunction and obesity. J Steroid Biochem Mol Biol. 2013;137: 99-106

110. Ji WJ, Ma YQ, Zhang $X$, et al. Inflammatory monocyte/macrophage modulation by liposome-entrapped spironolactone ameliorates acute lung injury in mice. Nanomedicine (Lond). 2016;11(11):1393-406. https://doi.org/ 10.2217/nnm-2016-0006.

111. SP-mediated mineralocorticoid receptor antagonism contributes to inflammatory monocyte/macrophage modulation via an inhibitory effect on Ly6C(hi) monocytosis-directed M2 polarization of alveolar macrophage.

112. Ji WJ, Ma YQ, Zhou X, et al. Spironolactone attenuates bleomycin-induced pulmonary injury partially via modulating mononuclear phagocyte phenotype switching in circulating and alveolar compartments. PLoS One 2013;8(11):e81090. Published 2013 Nov 19. doi:https://doi.org/10.1371/ journal.pone.0081090.

113. Rafatian N, Westcott KV, White RA, Leenen FH. Cardiac macrophages and apoptosis after myocardial infarction: effects of central MR blockade. Am J Physiol Regul Integr Comp Physiol. 2014;307(7):R879-87. https://doi.org/10. 1152/ajpregu.00075.2014

114. Zhang L, Hao JB, Ren LS, Ding JL, Hao LR. The aldosterone receptor antagonist spironolactone prevents peritoneal inflammation and fibrosis. Lab Invest. 2014;94(8):839-50. https://doi.org/10.1038/labinvest.2014.69.

115. Ozacmak HS, Ozacmak VH, Barut F, Araslı M, Ucan BH. Pretreatment with mineralocorticoid receptor blocker reduces intestinal injury induced by ischemia and reperfusion: involvement of inhibition of inflammatory response, oxidative stress, nuclear factor $\mathrm{kB}$, and inducible nitric oxide synthase. J Surg Res. 2014;191(2):350-61. https://doi.org/10.1016/j.jss.2014.04.040.

116. Kato $Y$, Kamiya $H$, Koide $N$, et al. Spironolactone inhibits production of proinflammatory mediators in response to lipopolysaccharide via inactivation of nuclear factor-kB. Immunopharmacol Immunotoxicol. 2014; 36(3):237-41. https://doi.org/10.3109/08923973.2014.921690.

117. Lieber GB, Fernandez X, Mingo GG, et al. Mineralocorticoid receptor antagonists attenuate pulmonary inflammation and bleomycin-evoked fibrosis in rodent models. Eur J Pharmacol. 2013;718(1-3):290-8. https://doi. org/10.1016/j.ejphar.2013.08.019.

118. Fraccarollo D, Galuppo P, Schraut S, et al. Immediate mineralocorticoid receptor blockade improves myocardial infarct healing by modulation of the inflammatory response. Hypertension. 2008:51(4):905-14.

119. Lacombe B, Morel M, Margottin-Goguet F, Ramirez BC. Specific Inhibition of HIV Infection by the Action of Spironolactone in T Cells. J Virol. 2016:90(23): 10972-10980. Published 2016 Nov 14. doi:https://doi.org/10.1128/JVl.01722-16.

120. Verma D, Thompson J, Swaminathan S. Spironolactone blocks Epstein-Barr virus production by inhibiting EBV SM protein function. Proc Natl Acad Sci U S A. 2016:113(13):3609-14. https://doi.org/10.1073/pnas.1523686113.

121. Yartaş Dumanlı G, Dilken O, Ürkmez S. Use of Spironolactone in SARS-CoV-2 ARDS Patients. Turk J Anaesthesiol Reanim 30 April 2020; DOI: 10.5152/ TJAR.2020.569.

122. https://clinicaltrials.gov/ct2/show/NCT04345887 (Last accessed: July $23^{\text {rd }}$ 2020).

123. https://clinicaltrials.gov/ct2/show/NCT04424134 (Last accessed: July $23^{\text {rd }}$ 2020).

124. https://clinicaltrials.gov/ct2/show/NCT04467931 (Last accessed: July 23 ${ }^{\text {rd }}, 2020$ ).

125. Rozner RN, Freites-Martinez A, Shapiro J, Geer EB, Goldfarb S, Lacouture ME. Safety of 5 a-reductase inhibitors and spironolactone in breast cancer patients receiving endocrine therapies. Breast Cancer Res Treat. 2019;174(1):15-26.

126. Almohanna HM, Perper M, Tosti A. Safety concerns when using novel medications to treat alopecia. Expert Opin Drug Saf. 2018;17(11):1115-28.

127. Andriole GL, Kirby R. Safety and tolerability of the dual 5alpha-reductase inhibitor dutasteride in the treatment of benign prostatic hyperplasia. Eur Urol. 2003;44(1):82-8. 
128. Mostaghel EA, Geng L, Holcomb I, et al. Variability in the androgen response of prostate epithelium to 5alpha-reductase inhibition: implications for prostate cancer chemoprevention. Cancer Res. 2010;70(4):1286-95.

129. Wu Y, Godoy A, Azzouni F, Wilton JH, Ip C, Mohler JL. Prostate cancer cells differ in testosterone accumulation, dihydrotestosterone conversion, and androgen receptor signaling response to steroid 5 a-reductase inhibitors. Prostate. 2013;73(13):1470-82

130. Tindall DJ, Rittmaster RS. The rationale for inhibiting 5alpha-reductase isoenzymes in the prevention and treatment of prostate cancer [published correction appears in J Urol. 2008 Jun;179(6):2490]. J Urol. 2008;179(4):1235-42.

131. Ghazizadeh Z, Majd H, Richter M, et al. Androgen Regulates SARS-CoV-2 Receptor Levels and Is Associated with Severe COVID-19 Symptoms in Men. Preprint. bioRxiv. 2020;2020.05.12.091082. Published 2020 May 15. doi: https://doi.org/10.1101/2020.05.12.091082.

132. Anti-androgens may protect against severe COVID-19 outcomes: results from a prospective cohort study of 77 hospitalized men. J Am Acad Derm. In review.

133. https://clinicaltrials.gov/ct2/show/NCT04446429 (Last accessed: July $23^{\text {rd }}$, 2020).

134. Bedi O, Dhawan V, Sharma PL, Kumar P. Pleiotropic effects of statins: new therapeutic targets in drug design. Naunyn Schmiedebergs Arch Pharmacol. 2016;389(7):695-712.

135. Zhou Q, Liao JK. Statins and cardiovascular diseases: from cholesterol lowering to pleiotropy. Curr Pharm Des. 2009;15(5):467-78.

136. Williams EA, Russo V, Ceraso S, Gupta D, Barrett-Jolley R. Anti-arrhythmic properties of non-antiarrhythmic medications. Pharmacol Res. 2020;156: 104762.

137. Fan E, Brodie D, Slutsky AS. Acute Respiratory Distress Syndrome: Advances in Diagnosis and Treatment. JAMA. 2018;319(7):698-710.

138. Feng $Y$. Efficacy of statin therapy in patients with acute respiratory distress syndrome/acute lung injury: a systematic review and meta-analysis. Eur Rev Med Pharmacol Sci. 2018;22(10):3190-8.

139. Xiong B, Wang C, Tan J, et al. Statins for the prevention and treatment of acute lung injury and acute respiratory distress syndrome: A systematic review and meta-analysis. Respirology. 2016;21(6):1026-33.

140. Yin J, Bai CX. Pharmacotherapy for Adult Patients with Acute Respiratory Distress Syndrome. Chin Med J (Engl). 2018;131(10):1138-41.

141. Grommes J, Vijayan S, Drechsler M, et al. Simvastatin reduces endotoxininduced acute lung injury by decreasing neutrophil recruitment and radical formation. PLoS One. 2012;7(6):e38917.

142. Fedson DS, Opal SM, Rordam OM. Hiding in Plain Sight: an Approach to Treating Patients with Severe COVID-19 Infection. mBio. 2020;11(2):e0039820. Published 2020 Mar 20

143. Castiglione V, Chiriacò M, Emdin M, Taddei S, Vergaro G. Statin therapy in COVID-19 infection [published online ahead of print, 2020 Apr 29]. Eur Heart J Cardiovasc Pharmacother. 2020;pvaa042.

144. Alijotas-Reig J, Esteve-Valverde E, Belizna C, et al. Immunomodulatory therapy for the management of severe COVID-19. Beyond the anti-viral therapy: A comprehensive review. Autoimmun Rev. 2020;19(7):102569.

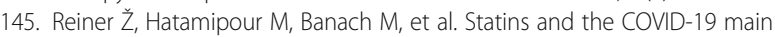
protease: in silico evidence on direct interaction. Arch Med Sci. 2020;16(3): 490-496. Published 2020 Apr 25.

146. Baudrand R, Pojoga LH, Vaidya A, et al. Statin Use and Adrenal Aldosterone Production in Hypertensive and Diabetic Subjects. Circulation. 2015;132(19): 1825-33.

147. Borghi C, Urso R, Cicero AF. Renin-angiotensin system at the crossroad of hypertension and hypercholesterolemia. Nutr Metab Cardiovasc Dis. 2017; 27(2):115-20.

148. Drapala A, Sikora M, Ufnal M. Statins, the renin-angiotensin-aldosterone system and hypertension - a tale of another beneficial effect of statins. J Renin Angiotensin Aldosterone Syst. 2014;15(3):250-8.

149. https://clinicaltrials.gov/ct2/show/NCT04407273 (Last accessed: July $23^{\text {rd }}$, 2020)

150. https://clinicaltrials.gov/ct2/show/NCT04348695 (Last accessed: July $23^{\text {rd }}$, 2020).

151. https://clinicaltrials.gov/ct2/show/NCT04466241 (Last accessed: July $23^{\text {rd }}$, 2020).

152. https://clinicaltrials.gov/ct2/show/NCT04380402 (Last accessed: July $23^{\text {rd }}$, 2020).

153. https://clinicaltrials.gov/ct2/show/NCT04343001 (Last accessed: July 23 ${ }^{\text {rd }}$, 2020).
154. https://linicaltrials.gov/ct2/show/NCT04472611 (Last accessed: July 23 ${ }^{\text {rd }}, 2020$ ).

155. Jakovac H. COVID-19 and vitamin D-Is there a link and an opportunity for intervention?. Am J Physiol Endocrinol Metab. 2020;318(5):E589. doi:https:// doi.org/10.1152/ajpendo.00138.2020.

156. Facchiano A, Facchiano A, Bartoli M, Ricci A, Facchiano F. Reply to Jakovac: About COVID-19 and vitamin D. Am J Physiol Endocrinol Metab. 2020; 318(6):E838.

157. Aygun H. Vitamin D can prevent COVID-19 infection-induced multiple organ damage [published online ahead of print, 2020 May 25]. Naunyn Schmiedebergs Arch Pharmacol. 2020;1-4.

158. Speeckaert MM, Delanghe JR. Association between low vitamin D and COVID-19: don't forget the vitamin D binding protein [published online ahead of print, 2020 May 28]. Aging Clin Exp Res. 2020;https://doi.org/10. 1007/s40520-020-01607-y.

159. Glinsky GV. Tripartite Combination of Candidate Pandemic Mitigation Agents: Vitamin D, Quercetin, and Estradiol Manifest Properties of Medicinal Agents for Targeted Mitigation of the COVID-19 Pandemic Defined by Genomics-Guided Tracing of SARS-CoV-2 Targets in Human Cells. Biomedicines. 2020;8(5):E129. Published 2020 May 21.

160. Grant WB, Lahore H, McDonnell SL, et al. Evidence that Vitamin D Supplementation Could Reduce Risk of Influenza and COVID-19 Infections and Deaths. Nutrients. 2020;12(4):988. Published 2020 Apr 2.

161. Teymoori-Rad M, Shokri F, Salimi V, Marashi SM. The interplay between vitamin D and viral infections. Rev Med Virol. 2019;29(2):e2032.

162. Zdrenghea MT, Makrinioti H, Bagacean C, Bush A, Johnston SL, Stanciu LA. Vitamin D modulation of innate immune responses to respiratory viral infections. Rev Med Virol. 2017;27(1). https://doi.org/10.1002/rmv.1909.

163. de Sa Del Fiol F, Barberato-Filho S, Lopes LC, de Cassia Bergamaschi C. Vitamin D and respiratory infections. J Infect Dev Ctries. 2015;9(4):355-361. Published 2015 Apr 15.

164. Bartley J. Vitamin D, innate immunity and upper respiratory tract infection. $J$ Laryngol Otol. 2010;124(5):465-9.

165. Gruber-Bzura BM. Vitamin D and Influenza-Prevention or Therapy?. Int J Mol Sci. 2018;19(8):2419. Published 2018 Aug 16

166. Beard JA, Bearden A, Striker R. Vitamin D and the anti-viral state. J Clin Virol. 2011;50(3):194-200.

167. Hastie CE, Mackay DF, Ho F, et al. Vitamin D concentrations and COVID-19 infection in UK Biobank [published online ahead of print, 2020 May 7]. Diabetes Metab Syndr. 2020;14(4):561-5.

168. Xu J, Yang J, Chen J, Luo Q, Zhang Q, Zhang H. Vitamin D alleviates lipopolysaccharide-induced acute lung injury via regulation of the reninangiotensin system. Mol Med Rep. 2017;16(5):7432-8.

169. Wang D, Chai XQ, Magnussen CG, et al. Renin-angiotensin-system, a potential pharmacological candidate, in acute respiratory distress syndrome during mechanical ventilation. Pulm Pharmacol Ther. 2019;58:101833.

170. Shi YY, Liu TJ, Fu JH, et al. Vitamin D/NDR signaling attenuates lipopolysaccharide-induced acute lung injury by maintaining the integrity of the pulmonary epithelial barrier. Mol Med Rep. 2016;13(2):1186-94.

171. Zheng S, Yang J, Hu X, et al. Vitamin D attenuates lung injury via stimulating epithelial repair, reducing epithelial cell apoptosis and inhibits TGF- $\beta$ induced epithelial to mesenchymal transition [published online ahead of print, 2020 Apr 3]. Biochem Pharmacol. 2020;113955:177.

172. Klaff LS, Gill SE, Wisse BE, et al. Lipopolysaccharide-induced lung injury is independent of serum vitamin D concentration. PLoS One. 2012;7(11):e49076.

173. Barnett N, Zhao Z, Koyama T, et al. Vitamin D deficiency and risk of acute lung injury in severe sepsis and severe trauma: a case-control study. Ann Intensive Care. 2014;4(1):5. Published 2014 Feb 24.

174. Li YC, Kong J, Wei M, Chen ZF, Liu SQ, Cao LP. 1,25-Dihydroxyvitamin D(3) is a negative endocrine regulator of the renin-angiotensin system. J Clin Invest. 2002;110(2):229-38.

175. Leung PS. The Modulatory Action of Vitamin D on the Renin-Angiotensin System and the Determination of Hepatic Insulin Resistance. Molecules. 2019;24(13):2479. Published 2019 Jul 5.

176. Turin A, Bax JJ, Doukas D, et al. Interactions Among Vitamin D, Atrial Fibrillation, and the Renin-Angiotensin-Aldosterone System. Am J Cardiol. 2018;122(5):780-4.

177. McMullan CJ, Borgi L, Curhan GC, Fisher N, Forman JP. The effect of vitamin $D$ on renin-angiotensin system activation and blood pressure: a randomized control trial. J Hypertens. 2017;35(4):822-9.

178. Washington MN. Weigel NL. 1\{alpha\},25-Dihydroxyvitamin D3 inhibits growth of VCaP prostate cancer cells despite inducing the growthpromoting TMPRSS2:ERG gene fusion. Endocrinology. 2010;151(4):1409-17. 
179. Murthy S, Agoulnik IU, Weigel NL. Androgen receptor signaling and vitamin D receptor action in prostate cancer cells. Prostate. 2005;64(4):362-72.

180. Mokhtari V, Afsharian P, Shahhoseini M, Kalantar SM, Moini A. A Review on Various Uses of N-Acetyl Cysteine. Cell J. 2017;19(1):11-7. https://doi.org/10. 22074/cellj.2016.4872.

181. Sekhar RV, Patel SG, Guthikonda AP, Reid M, Balasubramanyam A, Taffet GE. Deficient synthesis of glutathione underlies oxidative stress in aging and can be corrected by dietary cysteine and glycine supplementation. Am J Clin Nutr. 2011;94:847-53.

182. Circu ML, Aw TY. Glutathione and apoptosis. Free Radic Res. 2008;42:689706.

183. Whillier S, Raftos JE, Chapman B, Kuchel PW. Role of N-acetylcysteine and cystine in glutathione synthesis in human erythrocytes. Redox Rep. 2009;14: 115-24.

184. Sekhar RV, McKay SV, Patel SG, Guthikonda AP, Reddy VT, Balasubramanyam A. Glutathione synthesis is diminished in patients with uncontrolled diabetes and restored by dietary supplementation with cysteine and glycine. Diabetes Care. 2011;34:162-7.

185. Kavanagh TJ, Grossmann A, Jaecks EP, Jinneman JC, Eaton DL, Martin GM. Proliferative capacity of human peripheral blood lymphocytes sorted on the basis of glutathione content. J Cell Physiol. 1990:145:472-80.

186. Kao SJ, Wang D, Lin HI, Chen HI. N-acetylcysteine abrogates acute lung injury induced by endotoxin. Clin Exp Pharmacol Physiol. 2006;33(1-2):3340.

187. Shen Y, Miao NJ, Xu JL, et al. N-acetylcysteine alleviates angiotensin Imediated renal fibrosis in mouse obstructed kidneys. Acta Pharmacol Sin. 2016;37(5):637-44.

188. Boesgaard S, Aldershvile J, Poulsen HE, Christensen S, Dige-Petersen H, Giese J. N-acetylcysteine inhibits angiotensin converting enzyme in vivo. J Pharmacol Exp Ther. 1993;265(3):1239-44.

189. Assimakopoulos SF, Marangos M. N-acetyl-cysteine may prevent COVID-19 associated cytokine storm and acute respiratory distress syndrome [published online ahead of print, 2020 Apr 22]. Med Hypotheses. 2020;140: 109778.

190. Andreou A, Trantza S, Filippou D, Sipsas N, Tsiodras S. COVID-19: The Potential Role of Copper and $\mathrm{N}$-acetylcysteine (NAC) in a Combination of Candidate Antiviral Treatments Against SARS-CoV-2. In Vivo. 2020;34(3 Suppl):1567-88.

191. Horowitz RI, Freeman PR. Three novel prevention, diagnostic, and treatment options for COVID-19 urgently necessitating controlled randomized trials [published online ahead of print, 2020 May 22]. Med Hypotheses. 2020;143: 109851.

192. Poe FL, Corn J. N-Acetylcysteine: A potential therapeutic agent for SARSCoV-2 [published online ahead of print, 2020 May 30]. Med Hypotheses. 2020:143:109862.

193. https://clinicaltrials.gov/ct2/show/NCT04374461 (Last accessed: July $23^{\text {rd }}$, 2020).

194. https://clinicaltrials.gov/ct2/show/NCT04419025 (Last accessed: July $23^{\text {rd }}$ 2020).

195. https://clinicaltrials.gov/ct2/show/NCT04458298 (Last accessed: July $23^{\text {rd }}$ 2020)

196. https:/clinicaltrials.gov/ct2/show/NCT0437028 (Last accessed: July $23^{\text {rd }}$, 2020).

197. https://clinicaltrials.gov/ct2/show/NCT04455243 (Last accessed: July $23^{\text {rd }}$, 2020)

198. https:/clinicaltrials.gov/ct2/show/NCT04466657 (Last accessed: July $23^{\text {rd }}$, 2020)

199. Brotons C, Benamouzig R, Filipiak KJ, Limmroth V, Borghi C. A systematic review of aspirin in primary prevention: is it time for a new approach? Am J Cardiovasc Drugs. 2015;15(2):113-33.

200. Win TT, Aye SN, Lau Chui Fern J, Ong Fei C. Aspirin and Reducing Risk of Gastric Cancer: Systematic Review and Meta-Analysis of the Observational Studies. J Gastrointestin Liver Dis. 2020;29(2):191-198. Published 2020 Jun 3.

201. Tacconelli S, Contursi A, Falcone L, et al. Characterization of cyclooxygenase-2 acetylation and prostanoid inhibition by aspirin in cellular systems [published online ahead of print, 2020 Jun 11]. Biochem Pharmacol. 2020;114094.

202. Burn J, Sheth $H$, Elliott $F$, et al. Cancer prevention with aspirin in hereditary colorectal cancer (Lynch syndrome), 10-year follow-up and registry-based 20-year data in the CAPP2 study: a double-blind, randomised, placebocontrolled trial. Lancet. 2020;395(10240):1855-63.
203. Bem D, Dretzke J, Stevens S, et al. Investigating the effectiveness of different aspirin dosing regimens and the timing of aspirin intake in primary and secondary prevention of cardiovascular disease: protocol for a systematic review. Syst Rev. 2015;4:88. Published 2015 Jun 19.

204. Meune C, Mourad JJ, Bergmann JF, Spaulding C. Interaction between cyclooxygenase and the renin-angiotensin-aldosterone system: rationale and clinical relevance. J Renin Angiotensin Aldosterone Syst. 2003;4(3):149-54.

205. Nawarskas JJ, Spinler SA. Does aspirin interfere with the therapeutic efficacy of angiotensin-converting enzyme inhibitors in hypertension or congestive heart failure? Pharmacotherapy. 1998;18(5):1041-52.

206. Gawrys J, Gawrys K, Szahidewicz-Krupska E, Derkacz A, Mochol J, Doroszko A. Interactions between the Cyclooxygenase Metabolic Pathway and the Renin-Angiotensin-Aldosterone Systems: Their Effect on Cardiovascular Risk, from Theory to the Clinical Practice. Biomed Res Int. 2018;2018:7902081. Published 2018 Oct 2.

207. Yu H, Ni YN, Liang ZA, Liang BM, Wang Y. The effect of aspirin in preventing the acute respiratory distress syndrome/acute lung injury: A meta-analysis. Am J Emerg Med. 2018;36(8):1486-91.

208. Tilgner J, von Trotha KT, Gombert A, et al. Aspirin, but Not Tirofiban Displays Protective Effects in Endotoxin Induced Lung Injury. PLoS One. 2016;11(9): e0161218. Published 2016 Sep 1.

209. Liang H, Ding X, Li H, Li L, Sun T. Association Between Prior Aspirin Use and Acute Respiratory Distress Syndrome Incidence in At-Risk Patients: A Systematic Review and Meta-Analysis. Front Pharmacol. 2020;11:738. Published 2020 May 19.

210. Schuliga M, Jaffar J, Berhan A, et al. Annexin A2 contributes to lung injury and fibrosis by augmenting factor Xa fibrogenic activity. Am J Physiol Lung Cell Mol Physiol. 2017;312(5):L772-82

211. Shi M, Wang L, Zhou J, et al. Direct factor Xa inhibition attenuates acute lung injury progression via modulation of the PAR-2/NF-KB signaling pathway. Am J Transl Res. 2018;10(8):2335-49.

212. https://clinicaltrials.gov/ct2/show/NCT04416048 (Last accessed: July $23^{\text {rd }}$, 2020).

213. https://clinicaltrials.gov/ct2/show/NCT04324463 (Last accessed: July 23 $3^{\text {rd }}$, 2020).

214. https://clinicaltrials.gov/ct2/show/NCT04394377 (Last accessed: July $23^{\text {rd }}$, 2020).

215. https://clinicaltrials.gov/ct2/show/NCT04333407 (Last accessed: July $23^{\text {rd }}$ 2020).

216. Kuba K, Imai Y, Rao S, Gao H, Guo F, Guan B, Huan Y, Yang P, Zhang Y, Deng W, Bao L, Zhang B, Liu G, Wang Z, Chappell MC, Liu Y, Zheng D, Leibbrandt A, Wada T, Slutsky AS, Liu D, Qin C, Jiang C, Penninger JM. A crucial role of angiotensin converting enzyme 2 (ACE2) in SARS coronavirus-induced lung injury. Nature Med 2005; 11:875-87.

217. Lu R, Zhao X, Li J, Niu P, Yang B, Wu H. et al. Genomic characterisation and epidemiology of 2019 novel coronavirus: Implications for virus origins and receptor binding. Lancet 2020;395:565-574.

218. Zhao Y, Zhao Z, Wang Y, Zhou Y, Ma Y, W Zuo. Single-cell RNA expression profiling of ACE-2, the putative receptor of wuhan 2019-ncov. 2020. bioRxiv, https://doi.org/10.1101/2020.01.26.919985

219. Liu W, Tao ZW, Lei W, et al. Analysis of factors associated with disease outcomes in hospitalized patients with 2019 novel coronavirus disease [published online ahead of print, 2020 Feb 28]. Chin Med J (Engl). 2020; https://doi.org/10.1097/CM9.0000000000000775.

220. Williams B, Zhang Y. Hypertension, renin-angiotensin-aldosterone system inhibition, and COVID-19. Lancet. 2020;395(10238):1671-1673.

221. South AM, Diz D, Chappell MC. COVID-19, ACE2 and the Cardiovascular Consequences [published online ahead of print, 2020 Mar 31]. Am J Physiol Heart Circ Physiol. 2020;https://doi.org/10.1152/ajpheart.00217.2020.

222. Vaduganathan M, Vardeny O, Michel T, McMurray JJV, Pfeffer MA, Solomon SD. Renin-Angiotensin-Aldosterone System Inhibitors in Patients with Covid19 [published online ahead of print, 2020 Mar 30]. N Engl J Med. 2020; https://doi.org/10.1056/NEJMsr2005760.

223. McKee DL, Sternberg A, Stange U, Laufer S, Naujokat C. Candidate drugs against SARS-CoV-2 and COVID-19. Pharmacol Res. 2020;157:104859. doi: https://doi.org/10.1016/j.phrs.2020.104859.

224. Gil C, Ginex T, Maestro I, et al. COVID-19: Drug targets and potential treatments [published online ahead of print, 2020 Jun 8]. J Med Chem. 2020;https://doi.org/10.1021/acs.jmedchem.0c00606.

225. https://clinicaltrials.gov/ct2/show/NCT04357535 (Last accessed: July $23^{\text {rd }}$, 2020). 
226. https://clinicaltrials.gov/ct2/show/NCT04353596 (Last accessed: July 23 ${ }^{\text {rd }}$, 2020).

227. https://clinicaltrials.gov/ct2/show/NCT04329195 (Last accessed: July 23 ${ }^{\text {rd }}$, 2020).

228. https://clinicaltrials.gov/ct2/show/NCT04322786 (Last accessed: July $23^{\text {rd }}$, 2020).

229. Shen LW, Mao HJ, Wu YL, Tanaka Y, Zhang W. TMPRSS2: A potential target for treatment of influenza virus and coronavirus infections. Biochimie. 2017; 142:1-10.

230. Uno Y. Camostat mesilate therapy for COVID-19 [published online ahead of print, 2020 Apr 29]. Intern Emerg Med. 2020;1-2.

231. Lobo-Galo N, Terrazas-López M, Martínez-Martínez A, Díaz-Sánchez ÁG. FDAapproved thiol-reacting drugs that potentially bind into the SARS-CoV-2 main protease, essential for viral replication [published online ahead of print, 2020 May 14].

232. https://clinicaltrials.gov/ct2/show/NCT04352400 (Last accessed: July $23^{\text {rd }}$, 2020).

233. https://clinicaltrials.gov/ct2/show/NCT04418128 (Last accessed: July $23^{\text {rd }}$, 2020).

234. https://clinicaltrials.gov/ct2/show/NCT04473053 (Last accessed: July $23^{\text {rd }}$, 2020).

235. https://clinicaltrials.gov/ct2/show/NCT04353284 (Last accessed: July $23^{\text {rd }}$, 2020).

236. https://clinicaltrials.gov/ct2/show/NCT04455815 (Last accessed: July $23^{\text {rd }}$, 2020).

237. https://clinicaltrials.gov/ct2/show/NCT04338906 (Last accessed: July 23 ${ }^{\text {rd }}$, 2020).

238. https://clinicaltrials.gov/ct2/show/NCT04321096 (Last accessed: July 23 ${ }^{\text {rd }}$, 2020).

239. https://clinicaltrials.gov/ct2/show/NCT04435015 (Last accessed: July $23^{\text {rd }}$, 2020).

240. https://clinicaltrials.gov/ct2/show/NCT04355052 (Last accessed: July $23^{\text {rd }}$, 2020).

241. https://clinicaltrials.gov/ct2/show/NCT04470544 (Last accessed: July 23 ${ }^{\text {rd }}$, 2020).

242. https://clinicaltrials.gov/ct2/show/NCT04374019 (Last accessed: July 23 ${ }^{\text {rd }}$, 2020).

243. Rastrelli G, Di Stasi V, Inglese F, et al. Low testosterone levels predict clinical adverse outcomes in SARS-CoV-2 pneumonia patients [published online ahead of print, 2020 May 20]. Andrology. 2020;https://doi.org/10.1111/andr. 12821.

244. Wright TJ, Dillon EL, Durham WJ, et al. A randomized trial of adjunct testosterone for cancer-related muscle loss in men and women. J Cachexia Sarcopenia Muscle. 2018;9(3):482-96.

245. Rolfe M, Kamel A, Ahmed MM, Kramer J. Pharmacological management of cardiac cachexia: a review of potential therapy options. Heart Fail Rev. 2019; 24(5):617-23.

246. Springer J, Springer Jl, Anker SD. Muscle wasting and sarcopenia in heart failure and beyond: update 2017. ESC Heart Fail. 2017;4(4):492-8.

247. Breithaupt-Faloppa AC, Correia CJ, Prado CM, Stilhano RS, Ureshino RP, Moreira LFP. 17ß-Estradiol, a potential ally to alleviate SARS-CoV-2 infection. Clinics (Sao Paulo). 2020;75:e1980.

248. Grandi G, Facchinetti F, Bitzer J. The gendered impact of coronavirus disease (COVID-19): do estrogens play a role? [published online ahead of print, 2020 May 29]. Eur J Contracept Reprod Health Care. 2020;1-2.

249. Suba Z. Prevention and therapy of COVID-19 via exogenous estrogen treatment for both male and female patients. J Pharm Pharm Sci. 2020;23(1): 75-85.

250. Manning JT, Fink B. Understanding COVID-19: Digit ratio (2D:4D) and sex differences in national case fatality rates [published online ahead of print, 2020 May 14]. Early Hum Dev. 2020;146:105074.

251. Stelzig KE, Canepa-Escaro F, Schiliro M, Berdnikovs S, Prakash YS, Chiarella SE. Estrogen regulates the expression of SARS-CoV-2 receptor ACE2 in differentiated airway epithelial cells. Am J Physiol Lung Cell Mol Physiol. 2020;318(6):L1280-1.

252. Di Stadio A, Della Volpe A, Ralli M. Ricci G. Gender differences in COVID-19 infection. The estrogen effect on upper and lower airways. Can it help to figure out a treatment? Eur Rev Med Pharmacol Sci. 2020;24(10):5195-6.

253. Cutolo M, Smith V, Paolino S. Understanding immune effects of oestrogens to explain the reduced morbidity and mortality in female versus male
COVID-19 patients. Comparisons with autoimmunity and vaccination. Clin Exp Rheumatol. 2020;38(3):383-6.

254. Doucet D, Badami C, Palange D, et al. Estrogen receptor hormone agonists limit trauma hemorrhage shock-induced gut and lung injury in rats. PLoS One. 2010;5(2):e9421. Published 2010 Feb 25.

255. Kan WH, Hsu JT, Schwacha MG, Choudhry MA, Bland Kl, Chaudry $H_{\text {. }}$ Estrogen ameliorates trauma-hemorrhage-induced lung injury via endothelial nitric oxide synthase-dependent activation of protein kinase $\mathrm{G}$. Ann Surg. 2008;248(2):294-302.

256. Hamidi SA, Dickman KG, Berisha H, Said SI. 17ß-estradiol protects the lung against acute injury: possible mediation by vasoactive intestinal polypeptide. Endocrinology. 2011;152(12):4729-37.

257. Kawasaki T, Chaudry $H$. The effects of estrogen on various organs: therapeutic approach for sepsis, trauma, and reperfusion injury. Part 1: central nervous system, lung, and heart. J Anesth. 2012;26(6):883-91.

258. Speyer CL, Rancilio NJ, McClintock SD, et al. Regulatory effects of estrogen on acute lung inflammation in mice. Am J Physiol Cell Physiol. 2005;288(4): C881-90.

259. Vieira RF, Breithaupt-Faloppa AC, Matsubara BC, et al. 17ß-Estradiol protects against lung injuries after brain death in male rats. J Heart Lung Transplant. 2018;37(11):1381-7.

260. Komukai K, Mochizuki S, Yoshimura M. Gender and the renin-angiotensinaldosterone system. Fundam Clin Pharmacol. 2010;24(6):687-98.

261. Hilliard LM, Sampson AK, Brown RD, Denton KM. The "his and hers" of the renin-angiotensin system. Curr Hypertens Rep. 2013;15(1):71-9.

262. O'Donnell E, Floras JS, Harvey PJ. Estrogen status and the renin angiotensin aldosterone system. Am J Physiol Regul Integr Comp Physiol. 2014;307(5): R498-500.

263. Kim H, Datta A, Talwar S, Saleem SN, Mondal D, Abdel-Mageed AB. Estradiol-ERß2 signaling axis confers growth and migration of CRPC cells through TMPRSS2-ETV5 gene fusion. Oncotarget. 2016;8(38):62820-62833. Published 2016 Aug 17.

264. Bonkhoff $H$, Berges $\mathrm{R}$. The evolving role of oestrogens and their receptors in the development and progression of prostate cancer. Eur Urol. 2009;55(3):533-42.

265. Connors JM, Levy JH. COVID-19 and its implications for thrombosis and anticoagulation. Blood. 2020;135(23):2033-40.

266. Haematology TL. COVID-19 coagulopathy: an evolving story. Lancet Haematol. 2020;7(6):e425.

267. Becker RC. COVID-19 update: Covid-19-associated coagulopathy. J Thromb Thrombolysis. 2020;50(1):54-67.

268. Scheres LJJ, van Hylckama Vlieg A, Ballieux BEPB, et al. Endogenous sex hormones and risk of venous thromboembolism in young women. J Thromb Haemost. 2019;17(8):1297-304

269. Laliberté F, Dea K, Duh MS, Kahler KH, Rolli M, Lefebvre P. Does the route of administration for estrogen hormone therapy impact the risk of venous thromboembolism? Estradiol transdermal system versus oral estrogen-only hormone therapy. Menopause. 2018;25(11):1297-305.

270. Simon JA, Laliberté F, Duh MS, et al. Venous thromboembolism and cardiovascular disease complications in menopausal women using transdermal versus oral estrogen therapy. Menopause. 2016;23(6):600-10.

271. Rovinski D, Ramos RB, Fighera TM, Casanova GK, Spritzer PM. Risk of venous thromboembolism events in postmenopausal women using oral versus non-oral hormone therapy: A systematic review and meta-analysis. Thromb Res. 2018;168:83-95.

272. Tadic M, Cuspidi C, Sala C. COVID-19 and diabetes: Is there enough evidence? [published online ahead of print, 2020 May 29]. J Clin Hypertens (Greenwich). 2020;https://doi.org/10.1111/jch.13912.

273. Cariou B, Hadjadj S, Wargny M, et al. Phenotypic characteristics and prognosis of inpatients with COVID-19 and diabetes: the CORONADO study [published online ahead of print, 2020 May 29]. Diabetologia. 2020;1-16.

274. Scheen AJ, Marre M, Thivolet C. Prognostic factors in patients with diabetes hospitalized for COVID-19: Findings from the CORONADO study and other recent reports [published online ahead of print, 2020 May 21]. Diabetes Metab. 2020;S1262-3636(20)30085-9.

275. Wang YW, He SJ, Feng $X$, et al. Metformin: a review of its potential indications. Drug Des Devel Ther. 2017;11:2421-2429. Published 2017 Aug 22.

276. Shurrab NT, Arafa EA. Metformin: A review of its therapeutic efficacy and adverse effects. Obes Med. 2020;17:100186.

277. Siang KC, Hasan SS. Metformin use amid COVID-19 pandemic [published online ahead of print, 2020 May 29]. J Med Virol. 2020;https://doi.org/10. 1002/jmv.26090. 
278. El-Arabey AA, Abdalla M. Metformin and COVID-19: A novel deal of an Old Drug [published online ahead of print, 2020 Apr 29]. J Med Virol. 2020; https://doi.org/10.1002/jmv.25958.

279. Menendez JA. Metformin and SARS-CoV-2: mechanistic lessons on air pollution to weather the cytokine/thrombotic storm in COVID-19 [published online ahead of print, 2020 May 27]. Aging (Albany NY). 2020;12:https://doi. org/10.18632/aging.103347.

280. Luo P, Qiu L, Liu Y, et al. Metformin Treatment Was Associated with Decreased Mortality in COVID-19 Patients with Diabetes in a Retrospective Analysis [published online ahead of print, 2020 May 21]. Am J Trop Med Hyg. 2020;https://doi.org/10.4269/ajtmh.20-0375.

281. Dalan R. Metformin, Neutrophils and COVID-19 Infection [published online ahead of print, 2020 May 21]. Diabetes Res Clin Pract. 2020;108230.

282. Penlioglou T, Papachristou S, Papanas N. COVID-19 and Diabetes Mellitus: May Old Anti-diabetic Agents Become the New Philosopher's Stone? [published online ahead of print, 2020 May 7]. Diabetes Ther. 2020;1-3.

283. Sharma S, Ray A, Sadasivam B. Metformin in COVID-19: A possible role beyond diabetes [published online ahead of print, 2020 Apr 30]. Diabetes Res Clin Pract. 2020;164:108183.

284. Tsaknis G, Siempos II, Kopterides P, et al. Metformin attenuates ventilatorinduced lung injury. Crit Care. 2012;16(4):R134.

285. Vaez H, Najafi M, Toutounchi NS, Barar J, Barzegari A, Garjani A. Metformin Alleviates Lipopolysaccharide-induced Acute Lung Injury through Suppressing Toll-like Receptor 4 Signaling. Iran J Allergy Asthma Immunol. 2016;15(6):498-507.

286. Jian MY, Alexeyev MF, Wolkowicz PE, Zmijewski JW, Creighton JR. Metformin-stimulated AMPK-a1 promotes microvascular repair in acute lung injury. Am J Physiol Lung Cell Mol Physiol. 2013;305(11):L844-55.

287. Zhang X, Shang F, Hui L, Zang K, Sun G. The alleviative effects of metformin for lipopolysaccharide-induced acute lung injury rat model and its underlying mechanism. Saudi Pharm J. 2017;25(4):666-70.

288. Yu LL, Zhu M, Huang Y, et al. Metformin relieves acute respiratory distress syndrome by reducing miR-138 expression. Eur Rev Med Pharmacol Sci. 2018;22(16):5355-63.

289. Ghavimi H, Sheidaei S, Vaez H, Zolali E, Asgharian P, Hamishehkar H. Metformin-attenuated sepsis-induced oxidative damages: a novel role for metformin. Iran J Basic Med Sci. 2018;21(5):469-75.

290. Tsai $W L$, Chang TH, Sun WC, et al. Metformin activates type I interferon signaling against HCV via activation of adenosine monophosphate-activated protein kinase. Oncotarget. 2017;8(54):91928-91937. Published 2017 Aug 14.

291. Xun YH, Zhang YJ, Pan QC, et al. Metformin inhibits hepatitis B virus protein production and replication in human hepatoma cells. J Viral Hepat. 2014; 21(8):597-603.

292. Xiao Y, Liu F, Li S, et al. Metformin promotes innate immunity through a conserved PMK-1/p38 MAPK pathway. Virulence. 2020;11(1):39-48.

293. Chen Y, Gu F, Guan JL. Metformin Might Inhibit Virus through Increasing Insulin Sensitivity. Chin Med J (Engl). 2018;131(3):376-7.

294. Diaz A, Romero M, Vazquez T, Lechner S, Blomberg BB, Frasca D. Metformin improves in vivo and in vitro $B$ cell function in individuals with obesity and Type-2 Diabetes. Vaccine. 2017;35(20):2694-700.

295. Lalau JD, Kajbaf F, Protti A, Christensen MM, De Broe ME, Wiernsperger N. Metformin-associated lactic acidosis (MALA): Moving towards a new paradigm. Diabetes Obes Metab. 2017;19(11):1502-12.

296. Shin SJ, Chung S, Kim SJ, et al. Effect of Sodium-Glucose Co-Transporter 2 Inhibitor, Dapagliflozin, on Renal Renin-Angiotensin System in an Animal Model of Type 2 Diabetes. PLoS One. 2016;11(11):e0165703. Published 2016 Nov 1.

297. Bonora BM, Avogaro A, Fadini GP. Extraglycemic Effects of SGLT2 Inhibitors: A Review of the Evidence. Diabetes Metab Syndr Obes. 2020;13:161-174. Published 2020 Jan 21.

298. Kuchay MS, Farooqui KJ, Mishra SK, Mithal A. Glucose Lowering Efficacy and Pleiotropic Effects of Sodium-Glucose Cotransporter 2 Inhibitors [published online ahead of print, 2020 Feb 1]. Adv Exp Med Biol. 2020;https://doi.org/ 10.1007/5584_2020_479.

299. Li L, Konishi Y, Morikawa T, et al. Effect of a SGLT2 inhibitor on the systemic and intrarenal renin-angiotensin system in subtotally nephrectomized rats. J Pharmacol Sci. 2018;137(2):220-223.

300. Tentolouris A, Vlachakis P, Tzeravini E, Eleftheriadou I, Tentolouris N. SGLT2 Inhibitors: A Review of Their Antidiabetic and Cardioprotective Effects. Int J Environ Res Public Health. 2019;16(16):2965. Published 2019 Aug 17. doi: https://doi.org/10.3390/ijerph16162965.
301. Petrykiv S, Laverman GD, de Zeeuw D, Heerspink HJL. Does SGLT2 inhibition with dapagliflozin overcome individual therapy resistance to RAAS inhibition?. Diabetes Obes Metab. 2018;20(1):224-227.

302. Schork A, Saynisch J, Vosseler A, et al. Effect of SGLT2 inhibitors on body composition, fluid status and renin-angiotensin-aldosterone system in type 2 diabetes: a prospective study using bioimpedance spectroscopy. Cardiovasc Diabetol. 2019;18(1):46. Published 2019 Apr 5.

303. https://dinicaltrials.gov/ct2/show/NCT04393246 (Last accessed: July $23^{\text {rd }}, 2020$ ).

304. https://linicaltrials.gov/ct2/show/NCT04350593 (Last accessed: July 23 ${ }^{\text {rd }}, 2020$ ).

305. Cure E, Cumhur Cure M. Can dapagliflozin have a protective effect against COVID-19 infection? A hypothesis [published online ahead of print, 2020 Apr 21]. Diabetes Metab Syndr. 2020;14(4):405-406.

306. Mirabelli M, Chiefari E, Puccio L, Foti DP, Brunetti A. Potential Benefits and Harms of Novel Antidiabetic Drugs During COVID-19 Crisis. Int J Environ Res Public Health. 2020;17(10):E3664. Published 2020 May 22.

307. Zhu T, Li C, Zhang X, et al. GLP-1 Analogue Liraglutide Enhances SP-A Expression in LPS-Induced Acute Lung Injury through the TTF-1 Signaling Pathway. Mediators Inflamm. 2018;2018:3601454. Published 2018 May 22.

308. Xu J, Wei G, Wang J, et al. Glucagon-like peptide-1 receptor activation alleviates lipopolysaccharide-induced acute lung injury in mice via maintenance of endothelial barrier function. Lab Invest. 2019;99(4):577-87.

309. Zhou F, Zhang Y, Chen J, Hu X, Xu Y. Liraglutide attenuates lipopolysaccharideinduced acute lung injury in mice. Eur J Pharmacol. 2016;791:735-40.

310. Rowlands J, Heng J, Newsholme P, Carlessi R. Pleiotropic Effects of GLP-1 and Analogs on Cell Signaling, Metabolism, and Function. Front Endocrinol (Lausanne). 2018;9:672. Published 2018 Nov 23.

311. Muskiet MHA, Wheeler DC, Heerspink HJL. New pharmacological strategies for protecting kidney function in type 2 diabetes [published correction appears in Lancet Diabetes Endocrinol. 2019 Feb 4;:]. Lancet Diabetes Endocrinol. 2019;7(5):397-412.

312. Jiménez DL, Babkowski MC, Miramontes González JP. GLP-1 and the reninangiotensin-aldosterone system. Lancet Diabetes Endocrinol. 2019;7(5):337.

313. Skov J, Pedersen M, Holst JJ, et al. Short-term effects of liraglutide on kidney function and vasoactive hormones in type 2 diabetes: a randomized clinical trial. Diabetes Obes Metab. 2016;18(6):581-9.

314. Skov J, Persson F, Frøkiær J, Christiansen JS. Tissue Renin-Angiotensin systems: a unifying hypothesis of metabolic disease. Front Endocrinol (Lausanne). 2014;5:23.

315. Skov J, Dejgaard A, Frøkiær J, et al. Glucagon-like peptide-1 (GLP-1): effect on kidney hemodynamics and renin-angiotensin-aldosterone system in healthy men. J Clin Endocrinol Metab. 2013;98(4):E664-71.

316. Li Y, Zhang Z, Yang L, et al. The MERS-CoV Receptor DPP4 as a Candidate Binding Target of the SARS-CoV-2 Spike [published online ahead of print, 2020 May 13]. iscience. 2020;23(6):101160.

317. Fadini GP, Morieri ML, Longato E, et al. Exposure to DPP-4 inhibitors and COVID-19 among people with type 2 diabetes. A case-control study [published online ahead of print, 2020 May 28]. Diabetes Obes Metab. 2020; https://doi.org/10.1111/dom.14097.

318. Dalan R. Is DPP4 inhibition a comrade or adversary in COVID-19 infection [published online ahead of print, 2020 May 19]. Diabetes Res Clin Pract. 2020;164:108216.

319. Strollo R, Pozzilli P. DPP4 inhibition: preventing SARS-CoV-2 infection and/or progression of COVID-19? [published online ahead of print, 2020 Apr 26]. Diabetes Metab Res Rev. 2020; https://doi.org/10.1002/dmrr.3330.

320. Bassendine MF, Bridge SH, McCaughan GW, Gorrell MD. COVID-19 and comorbidities: A role for dipeptidyl peptidase 4 (DPP4) in disease severity? [published online ahead of print, 2020 May 11]. J Diabetes. 2020; https://doi. org/10.1111/1753-0407.13052.

321. Kawasaki T, Chen W, Htwe YM, Tatsumi K, Dudek SM. DPP4 inhibition by sitagliptin attenuates LPS-induced lung injury in mice. Am J Physiol Lung Cell Mol Physiol. 2018;315(5):L834-45.

322. Suzuki T, Tada Y, Gladson S, et al. Vildagliptin ameliorates pulmonary fibrosis in lipopolysaccharide-induced lung injury by inhibiting endothelial-tomesenchymal transition. Respir Res. 2017;18(1):177. Published 2017 Oct 16.

323. Beckers PAJ, Gielis JF, Van Schil PE, Adriaensen D. Lung ischemia reperfusion injury: the therapeutic role of dipeptidyl peptidase 4 inhibition. Ann Transl Med. 2017;5(6):129.

324. Guo K, Jin F. Dipeptidyl peptidase-4 (DPP-4) inhibitor saxagliptin alleviates lipopolysaccharide-induced acute lung injury via regulating the $\mathrm{Nrf}-2 / \mathrm{HO}-1$ and NF-kB pathways [published online ahead of print, 2019 Nov 7]. J Invest Surg. 2019;1-8. 
325. Letko M, Miazgowicz K, McMinn R, et al. Adaptive Evolution of MERS-CoV to Species Variation in DPP4. Cell Rep. 2018;24(7):1730-7.

326. Wang $N$, Shi $X$, Jiang $L$, et al. Structure of MERS-CoV spike receptor-binding domain complexed with human receptor DPP4. Cell Res. 2013;23(8):986-93.

327. Peck KM, Scobey T, Swanstrom J, et al. Permissivity of Dipeptidyl Peptidase 4 Orthologs to Middle East Respiratory Syndrome Coronavirus Is Governed by Glycosylation and Other Complex Determinants. J Virol. 2017;91(19): e00534-17.

328. Dastan F, Abedini A, Shahabi S, Kiani A, Saffaei A, Zare A. Sitagliptin Repositioning in SARS-CoV-2: Effects on ACE-2, CD-26, and Inflammatory Cytokine Storms in the Lung. Iran J Allergy Asthma Immunol. 2020;19(S1): $10-2$.

329. https://clinicaltrials.gov/ct2/show/NCT04382794 (Last accessed: July 23d, 2020).

330. https://clinicaltrials.gov/ct2/show/NCT04365517 (Last accessed: July 23 ${ }^{\text {rd }}$, 2020).

331. https://clinicaltrials.gov/ct2/show/NCT04341935 (Last accessed: July 23', 2020).

332. Carboni E, Carta AR, Carboni E. Can pioglitazone be potentially useful therapeutically in treating patients with COVID-19? [published online ahead of print, 2020 Apr 22]. Med Hypotheses. 2020;140:109776.

333. Kvandova M, Barancik M, Balis P, Puzserova A, Majzunova M, Dovinova I. The peroxisome proliferator-activated receptor gamma agonist pioglitazone improves nitric oxide availability, renin-angiotensin system and aberrant redox regulation in the kidney of pre-hypertensive rats. J Physiol Pharmacol. 2018;69(2):https://doi.org/10.26402/jpp.2018.2.09.

334. Zhang W, Li C, Liu B, et al. Pioglitazone upregulates hepatic angiotensin converting enzyme 2 expression in rats with steatohepatitis. Ann Hepatol. 2013;12(6):892-900.

335. Zhang W, Xu YZ, Liu B, et al. Pioglitazone upregulates angiotensin converting enzyme 2 expression in insulin-sensitive tissues in rats with high-fat diet-induced nonalcoholic steatohepatitis. ScientificWorldJournal. 2014;2014:603409. Published 2014 Jan 14.

336. Kurisu S, Iwasaki T, Ishibashi K, et al. Effects of low-dose pioglitazone on glucose control, lipid profiles, renin-angiotensin-aldosterone system and natriuretic peptides in diabetic patients with coronary artery disease. J Renin Angiotensin Aldosterone Syst. 2013;14(1):51-5.

337. Kutsukake M, Matsutani T, Tamura K, et al. Pioglitazone attenuates lung injury by modulating adipose inflammation. J Surg Res. 2014;189(2):295-303.

338. Matsutani T, Tamura K, Kutsukake M, Matsuda A, Tachikawa E, Uchida E. Impact of Pioglitazone on Macrophage Dynamics in Adipose Tissues of Cecal Ligation and Puncture-Treated Mice. Biol Pharm Bull. 2017;40(5):63844.

339. Grommes J, Mörgelin M, Soehnlein O. Pioglitazone attenuates endotoxininduced acute lung injury by reducing neutrophil recruitment. Eur Respir J. 2012;40(2):416-23.

340. Kaplan J, Nowell M, Chima R, Zingarelli B. Pioglitazone reduces inflammation through inhibition of NF-KB in polymicrobial sepsis. Innate Immun. 2014;20(5):519-28.

341. Ciavarella C, Motta I, Valente S, Pasquinelli G. Pharmacological (or Synthetic) and Nutritional Agonists of PPAR- $\gamma$ as Candidates for Cytokine Storm Modulation in COVID-19 Disease. Molecules. 2020;25(9):2076.

342. Chojkier M, Elkhayat H, Sabry D, Donohue M, Buck M. Pioglitazone decreases hepatitis $C$ viral load in overweight, treatment naïve, genotype 4 infected-patients: a pilot study. PLoS One. 2012;7(3):e31516.

343. Fukano K, Tsukuda S, Oshima M, et al. Troglitazone Impedes the Oligomerization of Sodium Taurocholate Cotransporting Polypeptide and Entry of Hepatitis B Virus Into Hepatocytes. Front Microbiol. 2019;9:3257. Published 2019 Jan 8.

344. Khattab M, Emad M, Abdelaleem A, et al. Pioglitazone improves virological response to peginterferon alpha-2b/ribavirin combination therapy in hepatitis C genotype 4 patients with insulin resistance. Liver Int. 2010;30(3):447-454.

345. Guerrero CA, Murillo A, Acosta O. Inhibition of rotavirus infection in cultured cells by N-acetyl-cysteine, PPARy agonists and NSAIDs [published correction appears in Antiviral Res. 2012 Nov;96(2):269. Guererero, Carlos A [corrected to Guerrero, Carlos A]]. Antiviral Res. 2012;96(1):1-12.

346. https://clinicaltrials.gov/ct2/show/NCT04473274 (Last accessed: July 23 $3^{\text {rd }}$, 2020)

347. Morath C, Ratzlaff K, Dechow C, et al. Chronic low-dose isotretinoin treatment limits renal damage in subtotally nephrectomized rats. J Mol Med (Berl). 2009;87(1):53-64.
348. Abdelmaksoud A, Vestita M, El-Amawy HS, et al. Systemic isotretinoin therapy in the era of COVID-19 [published online ahead of print, 2020 May 1]. Dermatol Ther. 2020:e13482. https://doi.org/10.1111/dth.13482.

349. https://clinicaltrials.gov/ct2/show/NCT04361422 (Last accessed: July 23rd, 2020).

350. https://clinicaltrials.gov/ct2/show/NCT04353180 (Last accessed: July $23^{\text {rd }}$, 2020).

351. https://clinicaltrials.gov/ct2/show/NCT04389580 (Last accessed: July $23^{\text {rd }}$, 2020).

352. https://clinicaltrials.gov/ct2/show/NCT04396067 (Last accessed: July 23 ${ }^{\text {rd }}$ 2020).

353. https://clinicaltrials.gov/ct2/show/NCT04382950 (Last accessed: July $23^{\text {rd }}$, 2020).

354. Vemuri VK, Janero DR, Makriyannis A. Pharmacotherapeutic targeting of the endocannabinoid signaling system: drugs for obesity and the metabolic syndrome. Physiol Behav. 2008;93(4-5):671-86.

355. Xie S, Furjanic MA, Ferrara JJ, et al. The endocannabinoid system and rimonabant: a new drug with a novel mechanism of action involving cannabinoid CB1 receptor antagonism--or inverse agonism--as potential obesity treatment and other therapeutic use. J Clin Pharm Ther. 2007;32(3): 209-31.

356. Topol EJ, Bousser MG, Fox KA, et al. Rimonabant for prevention of cardiovascular events (CRESCENDO): a randomised, multicentre, placebocontrolled trial. Lancet. 2010;376(9740):517-23.

357. Ludtke DD, Siteneski A, de Oliveira Galassi T, et al. High-intensity swimming exercise reduces inflammatory pain in mice by activation of the endocannabinoid system [published online ahead of print, 2020 May 1]. Scand I Med Sci Sports.

358. Kaser S, Ebenbichler CF, Tilg H. Pharmacological and non-pharmacological treatment of non-alcoholic fatty liver disease. Int J Clin Pract. 2010;64(7): $968-83$.

359. Schaich CL, Shaltout HA, Brosnihan KB, Howlett AC, Diz DI. Acute and chronic systemic $C B 1$ cannabinoid receptor blockade improves blood pressure regulation and metabolic profile in hypertensive (mRen2)27 rats. Physiol Rep. 2014;2(8):e12108.

360. Ciaglia E, Vecchione C, Puca AA. COVID-19 Infection and Circulating ACE2 Levels: Protective Role in Women and Children. Front Pediatr. 2020;8:206. Published 2020 Apr 23.

361. Mestre L, Carrillo-Salinas FJ, Mecha M, Feliú A, Guaza C. Gut microbiota, cannabinoid system and neuroimmune interactions: New perspectives in multiple sclerosis. Biochem Pharmacol. 2018;157:51-66.

362. Angelina A, Pérez-Diego M, López-Abente J, Palomares O. The Role of Cannabinoids in Allergic Diseases [published online ahead of print, 2020 Jun 11]. Int Arch Allergy Immunol. 2020:1-20.

363. Rieder SA, Chauhan A, Singh U, Nagarkatti M, Nagarkatti P. Cannabinoidinduced apoptosis in immune cells as a pathway to immunosuppression. Immunobiology. 2010;215(8):598-605.

364. Briand-Mésange F, Trudel S, Salles J, Ausseil J, Salles JP, Chap H. Possible Role of Adipose Tissue and Endocannabinoid System in COVID-19 Pathogenesis: Can Rimonabant Return? [published online ahead of print, 2020 May 28]. Obesity (Silver Spring). 2020;10.1002/oby.22916.

365. Rossi F, Tortora C, Argenziano M, Di Paola A, Punzo F. Cannabinoid Receptor Type 2: A Possible Target in SARS-CoV-2 (CoV-19) Infection?. Int Mol Sci. 2020;21(11):E3809. Published 2020 May 27.

366. Huang SA, Lie JD. Phosphodiesterase-5 (PDE5) Inhibitors In the Management of Erectile Dysfunction. P T. 2013;38(7):407-19.

367. Wang G, Zhang Q, Yuan W, Wu J, Li C. Sildenafil Protects against Myocardial Ischemia-Reperfusion Injury Following Cardiac Arrest in a Porcine Model: Possible Role of the Renin-Angiotensin System. Int J Mol Sci. 2015;16(11): 27015-27031. Published 2015 Nov 12.

368. Kosutova P, Mikolka P, Balentova S, et al. Effects of phosphodiesterase 5 inhibitor sildenafil on the respiratory parameters, inflammation and apoptosis in a saline lavage-induced model of acute lung injury. J Physiol Pharmacol. 2018;69(5):https://doi.org/10.26402/jpp.2018.5.15.

369. Guerra-Mora JR, Perales-Caldera E, Aguilar-León D, et al. Effects of Sildenafil and Tadalafil on Edema and Reactive Oxygen Species Production in an Experimental Model of Lung Ischemia-Reperfusion Injury. Transplant Proc. 2017:49(6):1461-6.

370. Gokakin AK, Deveci K, Kurt A, et al. The protective effects of sildenafil in acute lung injury in a rat model of severe scald burn: A biochemical and histopathological study. Burns. 2013;39(6):1193-9. 
371. Kniotek M, Boguska A. Sildenafil Can Affect Innate and Adaptive Immune System in Both Experimental Animals and Patients. J Immunol Res. 2017; 2017:4541958.

372. https://clinicaltrials.gov/ct2/show/NCT04304313 (Last accessed: July 23 $3^{\text {rd }}$, 2020).

373. Morgante G, Delia A, Musacchio MC, Severi FM, Petraglia F, De Leo V. Effects of raloxifene therapy on plasma renin and aldosterone levels and blood pressure in postmenopausal women. Gynecol Endocrinol. 2006;22(7):376-80.

374. Sumino H, Ichikawa S, Kasama S, et al. Effects of raloxifene on the reninangiotensin-aldosterone system and blood pressure in hypertensive and normotensive osteoporotic postmenopausal women. Geriatr Gerontol Int 2010;10(1):70-7.

375. Zhou GJ, Zhang H, Zhi SD, et al. Protective effect of raloxifene on lipopolysaccharide and acid- induced acute lung injury in rats. Acta Pharmacol Sin. 2007:28(10):1585-90.

376. Ellis AJ, Hendrick VM, Williams R, Komm BS. Selective estrogen receptor modulators in clinical practice: a safety overview [published correction appears in Expert Opin Drug Saf. 2015;14(11):1799-1800].

377. Boyack M, Lookinland S, Chasson S. Efficacy of raloxifene for treatment of menopause: a systematic review. J Am Acad Nurse Pract. 2002;14(4):150-65.

378. Shekarforoush S, Koohpeyma F, Safari F. Alteration at transcriptional level of cardiac renin-angiotensin system by letrozole treatment. Acta Cardiol. 2019; 74(2):109-13.

379. Chanplakorn N, Chanplakorn P, Suzuki T, et al. Increased 5a-reductase type 2 expression in human breast carcinoma following aromatase inhibitor therapy: the correlation with decreased tumor cell proliferation. Horm Cancer. 2011;2(1):73-81.

380. Takagi K, Miki Y, Nagasaki S, et al. Increased intratumoral androgens in human breast carcinoma following aromatase inhibitor exemestane treatment. Endocr Relat Cancer. 2010;17(2):415-430. Published 2010 Apr 21

381. Hierweger AM, Engler JB, Friese MA, et al. Progesterone modulates the Tcell response via glucocorticoid receptor-dependent pathways. Am J Reprod Immunol. 2019;81(2):e13084.

382. Oelkers W. The renin-aldosterone system and drospirenone. Gynecol Endocrinol. 2002;16(1):83-7.

383. Keller-Wood M, Silbiger J, Wood CE. Progesterone-cortisol interaction in control of renin activity but not aldosterone. Am J Physiol. 1990;259(2 Pt 2): R350-6.

384. Rogosnitzky M, Berkowitz E, Jadad AR. Delivering Benefits at Speed Through Real-World Repurposing of Off-Patent Drugs: The COVID-19 Pandemic as a Case in Point. JMIR Public Health Surveill. 2020;6(2):e19199. Published 2020 May 13.

385. https://clinicaltrials.gov/ct2/show/NCT04365127 (Last accessed: July $23^{\text {rd }}$ 2020).

386. Jean SS, Hsueh PR. Old and re-purposed drugs for the treatment of COVID19 [published online ahead of print, 2020 Jun 1]. Expert Rev Anti Infect Ther. 2020;1-5.

387. https://clinicaltrials.gov/ct2/show/NCT04356417 (Last accessed: July 23 ${ }^{\text {rd }}$, 2020).

\section{Publisher's Note}

Springer Nature remains neutral with regard to jurisdictional claims in published maps and institutional affiliations.

Ready to submit your research? Choose BMC and benefit from:

- fast, convenient online submission

- thorough peer review by experienced researchers in your field

- rapid publication on acceptance

- support for research data, including large and complex data types

- gold Open Access which fosters wider collaboration and increased citations

- maximum visibility for your research: over $100 \mathrm{M}$ website views per year

At $\mathrm{BMC}$, research is always in progress.

Learn more biomedcentral.com/submissions 